\title{
An integrated model of capital structure to study the differences in the speed of adjustment to target corporate debt maturity among developed countries
}

\author{
Eleuterio Vallelado* \\ Research Group (GR144), \\ University of Valladolid, \\ 6 Valle de Esgueva Av., 47011, Valladolid, Spain \\ Fax: +34-983183830 \\ E-mail: teyo@eco.uva.es \\ *Corresponding author
}

\author{
Paolo Saona \\ Business and Economics Department, \\ Saint Louis University, \\ Madrid Campus, 34 Del Valle Av., 28003, Madrid, Spain \\ Fax: +34-915546202 \\ E-mail: psaonaho@slu.edu
}

\begin{abstract}
In this paper, we propose an integrated model of capital structure to study the partial adjustment process to the optimal long term debt ratio. In our analysis, we consider the characteristics of the institutional environment as a factor that influences such adjustment. We use a sample of quoted firms from Germany, Denmark, Spain, Italy, USA, Australia, Belgium, UK and France for the period 1996-2008. The key findings are that the firms follow optimal long-term debt ratios. Such optimal ratios are determined by firm characteristics identified in the trade-off, pecking order and market timing theories and by the country institutional environment. We observe that in those countries with lower cost of adjustment, essentially in those where banks are the main source of funds, firms can reach their target debt ratio in half the time needed by those countries with higher adjustment costs.
\end{abstract}

Keywords: capital structure; target debt maturity; institutional environment; panel data.

Reference to this paper should be made as follows: Vallelado, E. and Saona, P. (2011) 'An integrated model of capital structure to study the differences in the speed of adjustment to target corporate debt maturity among developed countries', Int. J. Banking, Accounting and Finance, Vol. 3, No. 4, pp.258-293.

Biographical notes: Eleuterio Vallelado is a Professor of Finance at the University of Valladolid. He obtained his Bachelor's degree in Economics and Business and his $\mathrm{PhD}$ at the University of Valladolid, Spain and MBA from Stern School of Business, New York University, USA. He has published widely in corporate finance, banking and behavioural finance areas. Author of several books, his articles can be found in Journal of Banking and Finance, Applied Economics, Financial Review, ABANTE, Spanish Review of Finance 
and Accounting, Universia Business Review, Cuadernos de Economía y Dirección de Empresas, among others. His research interest include: corporate finance, corporate governance in banks, and behavioural finance.

Paolo Saona is an Assistant Professor of Finance at Saint Louis University's Madrid Campus in Spain. He received his $\mathrm{PhD}$ at the University of Valladolid, Spain, and his MBA and BSc in Business at Austral University of Chile. He is an active researcher and has published his works in several national and international academic journals such as the Applied Economics, the Spanish Journal of Finance and Accounting, ABANTE and Research Management, among others. His research fields are corporate finance (basically capital structure decisions), corporate governance, and financial systems. He has served as a reviewer for international journals.

\section{Introduction}

The debt structure of companies is related to a combination of factors including not only the characteristics of the firm, but also the macroeconomic and institutional environment. Most of the studies about target debt maturity have focused on individual countries but there is a growing literature that considers how macroeconomic and institutional differences affect companies' debt choices (Korajczyk and Levy, 2003).

The target debt maturity ratio of a company is a trade-off between the benefits and inconveniences that the debt maturity affords. Longer maturities benefit from higher tax shields, lower liquidation risk, and the disciplinary role of the debt; shorter maturities imply lower costs, higher risk of financial distress, or reduced agency problems like sub-investment and risk shifting. Graham and Harvey (2001) in the USA, Beattie et al. (2006) in the UK and Lindblom et al. (2010) in Sweden have used surveys to conclude that the majority of firms have a target for the structure of their debt, and that firm managers care more about bankruptcy disadvantages of debt than in its tax advantages. A firm that uses more short-term debt has to face more frequent renegotiations and therefore is more likely to be affected by a credit supply shock and might face financial constraints (Custodio et al., 2010).

Our research deals with debt maturity targets taking into account that the volume of long-term debt issued by the companies is influenced not only by firm characteristics, but also by the different roles that financial intermediaries play in the process of adjustment to the optimal structure (Miguel and Pindado, 2001; Ozkan, 2002). The behaviour of the suppliers of funds in different institutional contexts affects the adjustment costs to the optimal debt maturity ratio, and therefore the speed of adjustment to the target debt structure. Following Haas and Peeters (2006), the term target ratio captures more accurately the idea that the 'optimum' in our model is actually a moving (dynamic) target rather than a 'fixed' one and because it emphasises the fact that the target maturity ratio is the debt maturity structure a firm is continuously trying to reach.

The aim of this article is to analyse the target debt maturity of companies in different financial environments to understand the mix of driving factors which determine its speed of adjustment. Our paper differs from other studies in that we examine the speed of adjustment to the target debt maturity ratio considering not only firms' characteristics but 
also the macroeconomic and institutional factors of the environment where they operate. Thus,

a we build an integrated dynamic model considering the main theories on capital structure decisions and the macroeconomic and institutional variables

b we relate and extend the previous literature focusing on one of the particularities less studied in the capital structure decisions: the differences in adjustment speed to the target debt maturity structure are supported by country and institutional setting variables

c we use the cluster analysis for grouping the countries in our sample by speed of adjustment, macroeconomic conditions, stock market development, banking industry and institutional index in two clusters - Continental European countries and Anglo Saxon countries

d we apply a suitable econometric methodology to deal with endogeneity problems and to consider the heterogeneity of individual firms.

Our results indicate that firms follow a target debt maturity according to the dynamic trade-off theory, the characteristics of the financial systems, and the institutional setting. Specifically, we observe that the adjustment speed is faster in the institutional environments of developed countries in Continental Europe where financial intermediates play a main role as the supplier of funds to quoted firms. The main role of financial intermediaries as purveyors of funds to finance firm investments benefits Continental Europe companies' flexibility in adjusting to their optimal debt maturity structure.

This article is organised as follows: Following the introduction, Section 2 discusses the theoretical arguments; Section 3 shows the theoretical model integrating the capital structure theories and macroeconomic and institutional variables; Section 4 introduces our data, variables and the main statistics of the sample; Section 5 summarises the econometric model; Section 6 includes the main results, and finally, in Section 7 we present our conclusions.

\section{Literature review}

The theoretical and empirical literature on debt maturity has examined three factors: first, that at any point in time firms are faced with the benefits and costs associated with debt maturity choices and that the trade-offs between these benefits and costs lead to target debt ratios; second, the existence of shocks and institutional conditions force companies to deviate from their targets temporarily; and third, the presence of certain factors prevent firms from immediately adjusting their maturity structure to the optimum.

Stiglitz (1974) formally establishes debt maturity irrelevance in perfect capital markets; however, the manifestation of imperfections leads to the use of debt maturity as an instrument to deal with such imperfections. One of these imperfections is agency costs. Two main issues are related with agency costs and debt maturity: sub-investment and risk shifting. The best solution for agency problems is the use of short-term debt (Myers, 1977), however agency problems are not always resolved by the use of shortterm debt (Ravid, 1996). 
Similarly, in an asymmetric information environment, those companies that fear re-evaluation (bad companies) will issue long-term debt, whereas those firms that benefit from re-evaluation (good companies) will issue short-term debt (Ravid, 1996). Berger et al. (2005) find an increase in average maturity for low-risk firms when informational asymmetries are reduced. Diamond (1991) proposes a trade-off between short-term and long-term debt. Given a firm's private information, short term debt allows for a reduction in borrowing costs whenever a firm receives good news and the debt is refinanced. Nevertheless, short-term debt involves a high liquidity risk, which is a loss of non-assignable control rents if lenders will not allow refinancing and the firm is liquidated. Good companies prefer long-term debt when control rents make premature liquidation a costly option, but good firms will benefit from short-term debt if, as they release new information, they are able to borrow on better terms. Recently, Diamond and He (2010) reinforce the trade-off proposal when they show that even if there is no significant news that arrives between the debt maturity and the investment, the firm will issue long-term debt to reduce debt overhang. The correlation of income with interest rates will affect debt maturity of companies: a positive correlation favours short-term debt, whereas a negative correlation favours long-term debt (Morris, 1976).

Other imperfections are taxes and the presence of bankruptcy costs ${ }^{1}$. Taxes provide an incentive to debt whereas bankruptcy costs put a limit on such advantage. Brick and Ravid (1991) examine the conditions under which there is a debt maturity trade-off due to taxes. Houston and Venkataraman (1994) identify the existence of an optimal mix of maturities due to bankruptcy costs. These costs increase as the value of the companies is reduced, or alternatively when the volatility of the profits increases (Fama and French, 2002).

The original static trade-off theory is a sub-theory of the general theory of capital structure. This is because there are only two assumptions that are raised: the first is the lack of fiscal incentives, and the second is the non-existence of bankruptcy costs (Krishnaswami et al., 1999; Myers, 1993). Additionally, the static model of trade-off is not completely useful in determining the target long-term debt maturity ratio: it is expected that firms will adjust to their target in a dynamic way (Fama and French, 2002), it fails to explain the dynamic nature of the debt structure, it doesn't permit the observation of the existence of a reversion toward a target, nor does it allow the observation of the adjustment process along time.

In accordance with Frank and Goyal (2003) and Welch (2004), the target maturity structure might be affected by a series of dynamic elements, which would advise against the application of the static trade-off theory to explain the capital structure of companies. In the same line of reasoning, Drobetz and Wanzenried (2006) argue that early tests of capital structure theories suffer from several shortcomings, the most serious of which is the application of a static framework of analysis instead of a dynamic one in the study of the adjustment process to the target. Thus, our research follows those studies which centre on the determination of an objective structure of debt maturity through the use of dynamic models (Flannery and Rangan, 2006; Haas and Peeters, 2006; Hovakimian et al., 2002; Lemmon et al., 2008; Vasiliou and Daskalakis, 2009; Wanzenried, 2006).

A static model may poorly explain certain differences between companies in a cross-section sample of data due to the fact that the actual and the target maturity ratios can differ (Strebulaev, 2007). The deviations in the level of target debt maturity have been widely recognised as elements that can cause problems in the interpretation of the results of static models. For example, Myers (1984, p.578) emphasises that "Any 
cross-sectional test of financing behavior should specify whether firms' debt ratios differ because they have different optimal ratios or because their actual ratios diverge from optimal ones".

Financial decisions can be explained not only in terms of capital structure theories based on firm fundamentals, but also by those variables associated with the institutional, legal, and cultural characteristics of the environment in which the companies operate (Djankov et al., 2008; González, 2009; Levine et al., 2000; López and Rodríguez, 2008; Talberg, et al., 2008; Utrero, 2007; Vasiliou and Daskalakis, 2009). As Banerjee et al. (2004) argue, the transaction costs of debt are determined by the firm's specific fundamentals and by the economic factors which have a significant impact on the adjustment costs to the target maturity structure. Empirically, Brounen et al. (2006) provide survey-based evidence for the pecking order and trade-off models which explain the speed of adjustment toward target leverage and the proportion of long and short-term debt financing relative to the financing deficit for European firms. They conclude that legal tradition, the level of market development, and the type of financial system affect the speed of adjustment as well as the proportion of long-term and short-term debt financing. Wanzenried (2006) studies specifically how the economic and institutional factors affect the dynamic movements of debt maturity ratios to their optimal levels in the UK and Continental European countries. Thus, general theories can be complemented through this line of reasoning which considers the institutional differences among the countries (Bancel and Mittoo, 2004). Utrero (2007) argues that the consideration of institutional variables in the micro-economic models significantly improves the understanding of decisions made regarding the capital structure decisions. ${ }^{2}$

In the same vein, Dewatripont and Tirole (1994) point out that companies with concentrated ownership should rely on commercial banks to find external funds. This is important particularly in those institutional environments where hostile takeovers are ineffective and the banking system is very well developed, such as in civil-law countries (Azofra et al., 2007). In this environment intermediate debt and concentrated ownership are complementary elements in the design of an optimal system of corporate government (Saona and Vallelado, 2010). In countries governed by civil law there are often legal vacuums and low levels of obedience to the laws. This situation leads to a less efficient development of financial markets, and a preference for financing through bank credits and private finance (Antoniou et al., 2008; Hovakimian et al., 2004; La Porta et al., 1997; Lööf, 2004; López, 2005; Modigliani and Perotti, 1997; Shleifer and Vishny, 1997). This leads us to conclude that companies in certain countries reach their objective debt maturity ratio more quickly due to lower adjustment costs. These adjustment costs take into account factors such as taxation, bankruptcy costs, renegotiation costs of debt, and the cost of debt issuance -which are usually greater in public than in private debt (Schnabel, 1984).

From the empirical point of view, Thakor (1996) shows that the presence of banking in Continental Europe and Japan facilitates the access to bank financing by companies, thereby reducing the adjustment costs of the target debt maturity. In a sample of large Spanish companies, Miguel and Pindado (2001) argue that the adjustment toward the objective ratio is produced at a relatively fast pace with the institutional context playing an important role. Moreover, Gaud et al. (2005) point out that the adjustment costs are lower in Spain than in the UK principally because of the role played by bank financing. Demirgüç-Kunt and Maksimovic (1999) find systematic differences in the use of long-term debt between developed and developing countries, and between small and 
large firms. In developed countries, firms have more long-term debt and a greater proportion of their total debt is held as long-term debt. This is true regardless of the firm's size across their sample of countries. Furthermore, they find strong evidence that large firms in countries with effective legal systems have more long-term debt relative to assets.

As a result of this, we can conclude that the institutional characteristics of countries with financial systems dominated by banks, rather than by capital markets, facilitate an adjustment to the target debt maturity due to lower adjustment costs (Booth et al., 2001; Hovakimian et al., 2004; Korajczyk and Levy, 2003; Rajan and Zingales, 1995; Utrero, 2007). Such observations suggest that both macroeconomic conditions and firmspecific factors drive variations in financing choices and that these variations differ with the degree of financial market constraints. The advantages of private debt, observed in some countries, considered alongside the close relationship with a particular bank, the capacity of the bank to exercise corporate control, lower costs of renegotiation of the debt, and the ability of the bank to gauge the actual financial situation of the companies which they finance, permit them to reach a target debt maturity structure in a more dynamic and rapid way. A very different situation is observed in those countries where the main source of corporate financing comes from the issuing of shares and through public debt, which require greater adjustment costs reducing the speed of adjustment to the target.

Keeping all these factors in mind, our hypothesis is that we should observe a higher speed of adjustment toward target corporate debt maturity in those institutional environments with lower adjustment costs. At the same time, we also hypothesise that due to market frictions and transaction costs, such adjustment is produced dynamically and partially.

\section{Integrated theoretical model}

The trade-off model argues that in a given period, under conditions of perfect capital markets, the corporate debt maturity of a company $i$ in the period $t\left(L T D_{i, t}\right)$ should be equal to the target debt maturity for company $i$ in the same period $\left(L T D_{i, t}^{*}\right)$. However, in the absence of perfect capital markets, the following process of adjustment should exist for company $i$ :

$$
L T D_{i, t}-L T D_{i, t-1}=\lambda\left(L T D_{i, t}^{*}-L T D_{i, t-1}\right)
$$

In this equation $\lambda$ corresponds to the speed of adjustment to the target debt maturity ${ }^{3}$. If this coefficient is equal to 1 , then the objective maturity is equal to the ratio of debt observed in the period, reaching expectations immediately and completely (Gujarati, 1990). If it is seen that $\lambda<1$, then a partial adjustment exists between the ratio of debt of the period $t-1$ to the period $t$.

The target debt maturity ratio of the company can be obtained from its fundamentals:

$$
\operatorname{LTD}_{i, t}^{*}=\beta_{0}+\sum_{j=1}^{n} \beta_{j} X_{j, i, t}+\beta_{k} \text { Institutional }_{c, t}
$$


In this equation $X_{j}$ represents the firm-specific variables, Institutional ${ }_{c}$ the variables related to the country where the firm operates that explain the debt maturity target, and $\beta_{j}$ measures how each variable influences the target ratio. The subscript $j$ refers to each of the firm specific variables considered, from 1 to $n$; the subscript $i$ refers to each of the companies considered in the study, the subscript $c$ refers to the different countries included in the sample.

The firm-specific variables widely used in previous literature are: the growth opportunities (Johnson, 1997a, 1997b; Rajan and Zingales, 1995), output decisions (Brander and Lewis, 1986; Etro, 2010; Guedes and Opler, 1996; Maksimovic, 1988; Wanzenried, 2003), the need for external funds to finance the project portfolio (Shyam-Sunder and Myers, 1999), the size of the company (Dennis and Sharpe, 2005; Johnson, 1997a; Krishnaswami and Subramaniam, 1999; Ozkan and Ozkan, 2004), return on company portfolio of projects (Rajan and Zingales, 1995; Titman and Wessels, 1988); the probability of bankruptcy (Altman, 1968; Andrés et al., 2005; Begley et al., 1996), and non-debt tax shield (NDTS) (De Angelo and Masulis, 1980; Graham, 1999; Modigliani and Miller, 1958; Schnabel, 1984).

The Institutional variable is a vector that summarises country specific variables such as macroeconomic conditions, the stock market and financial institutions development, and the institutional indexes.

Therefore, substituting equation (2) in equation (1) and reordering the terms in function of $L T D_{i, t}$, we have our integrated dynamic model:

$$
L T D_{i, t}=\lambda \cdot \beta_{0}+(1-\lambda) \cdot \operatorname{LTD}_{i, t-1}+\lambda \cdot\left(\sum_{j=1}^{n} \beta_{j} X_{j, i, t}\right)+\lambda \cdot\left(\beta_{k} \cdot \text { Instituional }_{c, t}\right)
$$

The parameter corresponding to the lagged dependent variable $(1-\lambda)$, equals the adjustment costs. Once an estimation of $\lambda$ is obtained through the dependent lagged variable $L T D_{i, t-1}$, we can compute the $\beta_{j}$ by dividing each coefficient of vector $X_{j, i, t}$ by $\lambda$. The speed of adjustment can be interpreted as the percentage of the target debt maturity achieved by the firm during one year. The higher the coefficient, the closer to the target the firm will be.

\section{Data, variables and statistics}

The sample used in this work needed to fulfil two important conditions: first, an acceptable mix between observations belonging to Continental European and Anglo Saxon countries had to be created; second, the economic conditions of the countries included into the sample had to show a homogeneous and comparable development along the period of analysis in order to minimise the bias due economic conditions of each country individually considered. To fulfil these two requirements, we built an unbalanced panel data of non-financial companies listed in Germany, Denmark, Spain, Italy, the USA, Australia, Belgium, the UK and France. All the countries included in our sample are OECD members, which guarantee some degree of harmonisation in terms of economic development and growth. For instance, they have experienced comparable growth in their GDP per capita and income levels; all have stable inflation rates, and roughly the same interest rates. Thus, given the goal of this paper, firms were selected 
from countries that are fairly homogeneous in their level of economic development, but that differ with respect to characteristics such as the relative relevance of banks and financial markets, the market for corporate control, and the legal system. Finally we have discarded some countries (e.g., Canada and Netherlands, among others) because they lacked the minimum number of firm-year observations needed by the empirical analysis to have statistically significant estimations and statistics.

The period of analysis extends from 1996 to $2008^{4}$. COMPUSTAT Database is our source of financial statement information from which we have gathered a total of 33,731 firm-year observations for non-financial quoted firms. Financial firms were excluded because their capital structures are likely to be significantly different from the capital structure of non-financial firms included in our sample. Firms with missing values for relevant variables are also excluded. In addition, we obtained data on macroeconomic conditions, the characteristics of financial systems, and institutional indices from the OECD database, the updated World Bank database (Beck et al., 2000), from La Porta et al. (2006), and from the Transparency International Annual Report.

Our dependent variable is the debt maturity ratio calculated as the quotient of the firm total long-term debt over the total debt (LTDTD), both at book value (Custodio et al., 2010). Whether to measure the ratio at market or book value is an issue of debate (Parsons and Titman, 2008). Those papers that use either measures of leverage achieve comparable results (Faulkender and Petersen, 2006; Flannery and Rangan, 2006; Huang and Ritter, 2009). Chen and Zhao (2006) argue that the book value of the debt maturity ratio implies the cumulative use of retained funds, debt and equity thereby revealing the financial policy of the firm. According to Lang et al. (1996) a measure based on market values could give too much importance to the recent changes in the equity. Additionally, Graham and Harvey (2001) provide survey evidence that managers are concerned mostly with book values. And so, based on these arguments, we use book values for the debt maturity ratio.

The descriptive statistics of Table 1, Panel A, reveal that for our sample the average firm has an observed long-term debt over total debt ratio of 39.42\%. In Panel B we observe that the Australian companies show the higher long-term debt over total debt ratio with $50.45 \%$, followed by the German and the US firms: $47.88 \%$ and $45.35 \%$ respectively; whereas the UK companies show the lowest at $20.89 \%$. Finally in Panel C, our data show that Continental European companies use a slightly higher proportion of long-term debt over total debt than Anglo Saxon companies: $40.35 \%$ versus $38.87 \%$ respectively.

The explanatory variables in our paper follow the debt maturity literature (Barclay and Smith, 1995; Custodio et al., 2010) and are supported by several theories (agency costs, signalling and liquidity risk, asymmetric information, and taxes). We measure the firms' growth opportunities with the market-to-book ratio of total assets (Q). The market-to-book ratio is a usual approximation to Tobin's $\mathrm{Q}$ which uses the cost of the reposition of assets instead of market values. This ratio $(\mathrm{Q})$ is defined as the market value of assets divided by the book value of assets, where the market value of assets is the book value of assets less common equity plus the stock market capitalisation (Andrés et al., 2005; Danbolt et al., 2002; Johnson, 1997a, 1997b; Lang et al., 1996; Miguel and Pindado, 2001; Ozkan, 2002; Ozkan and Ozkan, 2004; Rajan and Zingales, 1995). ${ }^{5}$ The descriptive statistics of Table 1, Panel A, reveal that for our sample, the average firm has growth opportunities because Q is higher than 1: 1.2793. By country, companies from Australia and the UK have the highest values, over 1.56, and the companies from 
Belgium and Denmark are the only ones with no growth opportunities on average, with values under 1: 0.622 and 0.5483 respectively. Companies operating in the Anglo Saxon environment show higher growth opportunities than those in Continental European countries: 1.3648 versus 1.1343 respectively.

Table 1 Descriptive statistics of the sample

\begin{tabular}{lccccc}
\hline \multicolumn{5}{c}{ Panel A. Whole sample } \\
\hline Variable & Obs & Mean & Std. Dev. & Min & Max \\
\hline LTDTD & 33,731 & 0.3942 & 0.2358 & 0.0000 & 0.9988 \\
Q & 33,731 & 1.2793 & 1.2042 & 0.0013 & 20.0850 \\
VSALES & 33,731 & 0.0697 & 0.2125 & -0.5989 & 0.7593 \\
DEF & 33,731 & 0.0162 & 0.2360 & -1.6237 & 3.6613 \\
Z & 33,731 & 1.3847 & 2.3667 & -10.0000 & 109.7901 \\
LNTAB & 33,731 & 12.2785 & 2.0192 & 3.7796 & 19.3784 \\
ROA & 33,731 & -0.0134 & 0.1685 & -0.9996 & 0.9996 \\
NDTS & 33,731 & 0.0243 & 0.0891 & 0.0000 & 0.9951 \\
& & & & & \\
\hline
\end{tabular}

\begin{tabular}{lccccccccc}
\hline \multicolumn{10}{c}{ Panel B. Per country } \\
\hline Variables & Germany & Denmark & Spain & Italy & USA & Australia & Belgium & UK & France \\
\hline LTDTD & 0.4788 & 0.3796 & 0.4199 & 0.4085 & 0.4535 & 0.5045 & 0.4257 & 0.2089 & 0.3391 \\
Q & 1.1918 & 0.5483 & 1.3020 & 1.2352 & 1.2726 & 1.5901 & 0.6220 & 1.5631 & 1.2262 \\
VSALES & 0.0644 & 0.0855 & 0.0833 & 0.0681 & 0.0650 & 0.0842 & 0.0886 & 0.0626 & 0.0870 \\
DEF & -0.0085 & -0.0447 & -0.0554 & -0.0089 & 0.0699 & -0.0387 & -0.0236 & -0.0116 & -0.0460 \\
Z & 1.7242 & 6.4509 & 1.3546 & 1.1038 & 0.6906 & 1.7904 & 4.1700 & 1.4848 & 1.6732 \\
LNTAB & 12.8790 & 12.4656 & 13.5058 & 13.2895 & 12.1586 & 12.3259 & 12.9504 & 11.5234 & 12.4068 \\
ROA & 0.0093 & 0.0404 & 0.0448 & 0.0085 & -0.0469 & 0.0499 & 0.0428 & -0.0168 & 0.0276 \\
NDTS & 0.0438 & 0.0337 & 0.0742 & 0.0751 & 0.0000 & 0.0410 & 0.0451 & 0.0307 & 0.0428 \\
Obs. & 3,804 & 977 & 923 & 1,390 & 14,585 & 856 & 728 & 5,806 & 4,662 \\
& & & & & & & & & \\
\hline
\end{tabular}

Notes: Panel A includes the mean, the standard deviation, minimum, and maximum of the following variables: long-term debt on total debt (LTDTD), market value of assets on book value of assets $(\mathrm{Q})$, the change in output measured as the percentage annual variation in sales (VSALES), deficit of funds for financing the variations in the working capital and in the fixed assets (DEF), the Altman Z-Score (Z), the natural logarithm of the total assets (LNTAB), the return on the total assets (ROA), and non-debt tax shield (NDTS) measures as the annual depreciation over total assets.

Panel B shows the mean for the same variables but for each country, in our case: Germany, Denmark, Spain, Italy, USA, Australia, Belgium, UK, and France. Panel $\mathrm{C}$ includes the variables described in panel A for two institutional settings: Continental Europe countries and Anglo Saxon countries. 
Table 1 Descriptive statistics of the sample (continued)

\begin{tabular}{lcc}
\hline \multicolumn{3}{c}{ Panel C. By institutional setting } \\
\hline \multirow{2}{*}{ Variables } & \multicolumn{2}{c}{ Mean } \\
\cline { 2 - 3 } & Continental Europe & Anglo Saxon \\
\hline LTDTD & 0.4035 & 0.3887 \\
Q & 1.1343 & 1.3648 \\
VSALES & 0.0773 & 0.0652 \\
DEF & -0.0296 & 0.0432 \\
Z & 2.1187 & 0.9520 \\
LNTAB & 12.7650 & 11.9917 \\
ROA & 0.0227 & -0.0347 \\
NDTS & 0.0486 & 0.0100 \\
Obs. & 12,484 & 21,247 \\
\hline
\end{tabular}

Notes: Panel A includes the mean, the standard deviation, minimum, and maximum of the following variables: long-term debt on total debt (LTDTD), market value of assets on book value of assets (Q), the change in output measured as the percentage annual variation in sales (VSALES), deficit of funds for financing the variations in the working capital and in the fixed assets (DEF), the Altman $\mathrm{Z}$-Score $(\mathrm{Z})$, the natural logarithm of the total assets (LNTAB), the return on the total assets (ROA), and non-debt tax shield (NDTS) measures as the annual depreciation over total assets.

Panel B shows the mean for the same variables but for each country, in our case: Germany, Denmark, Spain, Italy, USA, Australia, Belgium, UK, and France.

Panel C includes the variables described in panel A for two institutional settings: Continental Europe countries and Anglo Saxon countries.

To measure how output decisions could influence the debt ratio we include the percentage variation in net sales each year. Here, the variation is, on average positive at $6.97 \%$. By countries, Belgian companies show the highest positive variation in sales, $8.86 \%$, and the UK, German and US companies the lowest. Continental European companies increase their sales yearly more than Anglo Saxon companies: $7.73 \%$ and $6.52 \%$ respectively.

The need for external funding (DEF) to finance the portfolio of projects has been calculated, following Shyam-Sunder and Myers (1999). Thus, DEF is the difference of fixed assets in $t$ and $t-1$, plus the difference of the working capital in $t$ and $t-1$, minus the cash flow in $t$, and all scaled by the total assets. If the variable shows a positive sign it means that the company needs funds to finance its investments, whereas a negative sign for the variable indicates an excess of funds or a surplus. The figures in Table 1, Panel A, indicate that on average the companies in our sample have a deficit of funds. By countries, only US companies have a deficit of funds on average with the Spanish companies showing the largest surplus of funds. The Continental European firms show on average a surplus of funds to finance their investments whereas the Anglo Saxon firms have a deficit of funds.

The size of the companies (LNTAB) is measured by the book value of their assets. For the econometric analysis we use its logarithmic transformation to avoid heterokedasticity problems (Haas and Peeters, 2006). The largest companies in our 
sample, on average, are from Italy and Spain and the smallest are, on average, in the UK. Continental European companies are, on average, larger in size than Anglo Saxon firms.

The company's return on assets (ROA) is our measure of profitability. The probability of bankruptcy has been estimated by the value of Altman's Z-Score $(Z)^{6}$; and the NDTS has been calculated as the annual depreciation over total assets. Other variables used in the study are the amortisation over total assets, or the fixed assets over total assets (Dennis and Sharpe, 2005; Faulkender and Petersen, 2006). However, the last two variables were not only redundant but statistically not significant in the regressions performed; we decided not to include these variables in the tables.

Our data show that, on average, the companies in our sample have a negative ROA of $1.34 \%$. The Australian companies exhibit the largest ROA on average, $4.99 \%$, whereas the US and the UK companies are the only ones with a negative ROA on average, $-4.69 \%$ and $-1.68 \%$ respectively. The Continental European companies have, on average, a positive and higher ROA than Anglo Saxon companies.

In accordance with the variable which measures the risk of bankruptcy $(Z)$ we see that companies in Belgium and Denmark present the highest Z-score values; thereby indicating less bankruptcy risk. On the other hand, we find companies from Italy and the US with the highest bankruptcy risk (lower values of Z-score). In particular, the US companies are the only ones that exhibit, as a group, a Z-score lower than 1, indicating the highest probability of bankruptcy. On average the companies of Continental European countries have lower bankruptcy risks than companies in the Anglo Saxon countries.

Companies in Italy and Spain show the highest proportion of depreciation expenses over total assets and thus could benefit the least from the debt tax deductions. At the opposite end are the US companies with a lower proportion of depreciation expenses. In the same vein, we observe that Anglo Saxon companies have lower proportion of depreciation expenses in comparison to Continental European companies.

The descriptive statistics identify differences among the countries in the range of variables related with firms' characteristics. These differences help to explain why we observe dissimilar adjustment processes to the target debt maturity ratio per country; these differences coincide with the presence of differing institutional environments. To account for the differences in the environment where the firms operate we have run a principal component analysis to summarise all the information we have collected about the institutional and legal characteristics by country (Demirgüç-Kunt and Maksimovic, $1998,1999,2002)$ in a reduced number of factors. The information or variables per country can be divided in four groups: macroeconomic conditions, the development of capital markets, the relevance of financial institutions in each country, and institutional indexes about investor protection, legal constraints, accounting standards and corruption (see Table 2).

In the first group, we include the variables that measure macroeconomic conditions such as GDP per capita, inflation, and interest rates. The second group considers variables that measure the relevance of capital markets in each country (Demirgüç-Kunt and Maksimovic, 1999). We measure the variable we call 'Relative Importance of Capital Markets' by the ratio of stock market capitalisation over deposit money bank assets. The variable 'Private Credit by Money Banks' measures the volume of private credit by financial institutions scaled by GDP. The access to publicly traded capital markets is measured by the ratio of 'Stock Market Capitalisation over GDP', and by the ratio 
'Public Bond Market Capitalisation over GDP', respectively for stocks and bonds. Firms will more often choose equity and public debt rather than bank debt for financing their operations if they operate in countries with developed and liquid capital markets, as long as the marginal cost of issuing new securities is lower than the marginal cost of long-term debt. In the third group we include the variables that measure the relevance of banking in a country: 'Bank Concentration', which is measured as the market share of the three largest banks; the 'Bank Assets on GDP' that reflects the claims on the domestic, real, non-financial sector by banks; and the 'Ownership Concentration' which corresponds to the average of shares held by the three major shareholders of listed firms. The last group of variables used to calculate the institutional characteristics of each country includes: the degree of protection to investors, the legal constraints for business and corporations, the quality of accounting standards, and the perception of corruption in each country.

The countries in our sample are quite similar in their macroeconomic conditions. The US has the highest GDP per capita at more than USD 37,767 and Spain, the lowest GDP per capital, at more than USD 24,000. The inflation rate per annum ranges from $1.7 \%$ in Germany and France to $3.2 \%$ in Spain, with most of the countries in the range of $2 \%$ to $3 \%$. The highest long term interest rates are in Australia, the UK and Italy, at $6 \%, 5.3 \%$ and $5.2 \%$ respectively, and the lowest in France and Germany, at $4.6 \%$. Finally, the lowest proportion of variation in interest rates is in the UK and Australia, where the short-term interest rates are higher than the long-term interest rates. In contrast, the biggest difference between long-term and short-term in interest rates is in France, Spain and Germany (see Table 2).

Capital markets are more relevant in Australia and the USA than in Germany or Denmark according to the World Bank Database (Beck et al., 2000). Stock market capitalisation is also higher in Anglo Saxon countries than in the Continental European countries. When we observe the relevance of banking in the sample countries, Table 2 indicates that bank concentration is particularly high in Belgium and Denmark, and relatively low in the USA. The highest proportion of bank assets over GDP is found in Denmark and the lowest in the USA. Continental European countries exhibit a banking industry with a higher relevance in their economies than the Anglo Saxon countries. Finally our data indicate that the USA and the UK have better protection for external investors and the best accounting standards among the countries in our sample. On the other end are Denmark and Germany which exhibit low values in protection for external investors and accounting standards indices. There are not big differences in legal constraints or corruption perception among the countries in the sample. Denmark is the country with the highest score in legal constraints and Spain shows the lowest score; Italy is the country with the highest corruption perception and Denmark has the lowest corruption perception index.

Thus, the figures in Table 2 highlight the importance of the roles played by the market as a source of funds for the companies in these countries in comparison with bank financing, and the different institutional environments in which the firms have to make their debt decisions.

Additionally, we combine firm specific variables that are significant determinants of the firm capital structure with the factors that measure macroeconomic, legal and institutional differences among countries (Flannery and Rangan, 2006; Frank and Goyal, 2009; Huang and Ritter, 2009) to study the target debt maturity ratio to which companies will adjust dynamically. 
Table 2 Comparative indicators by country

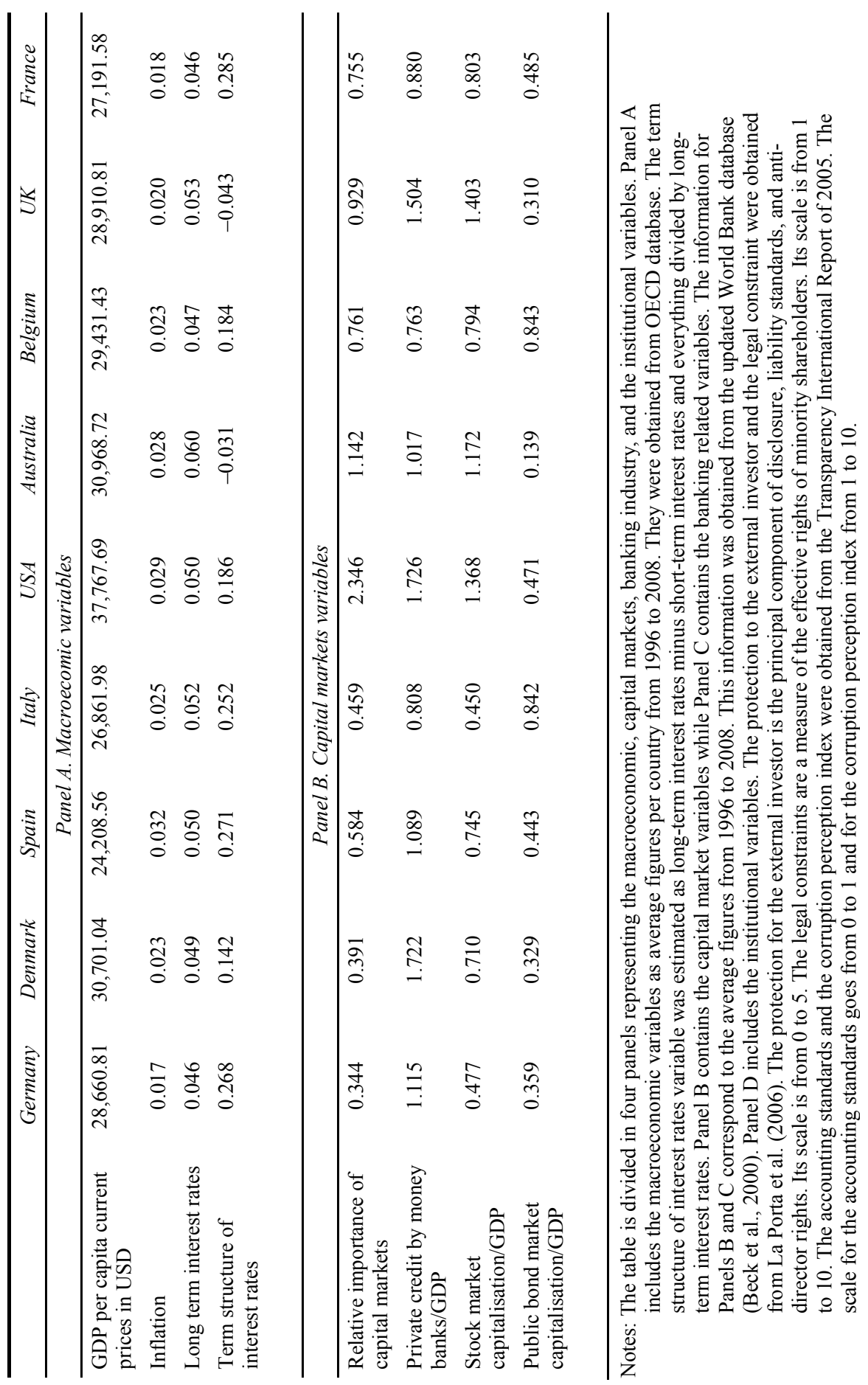


Table 2 Comparative indicators by country (continued)

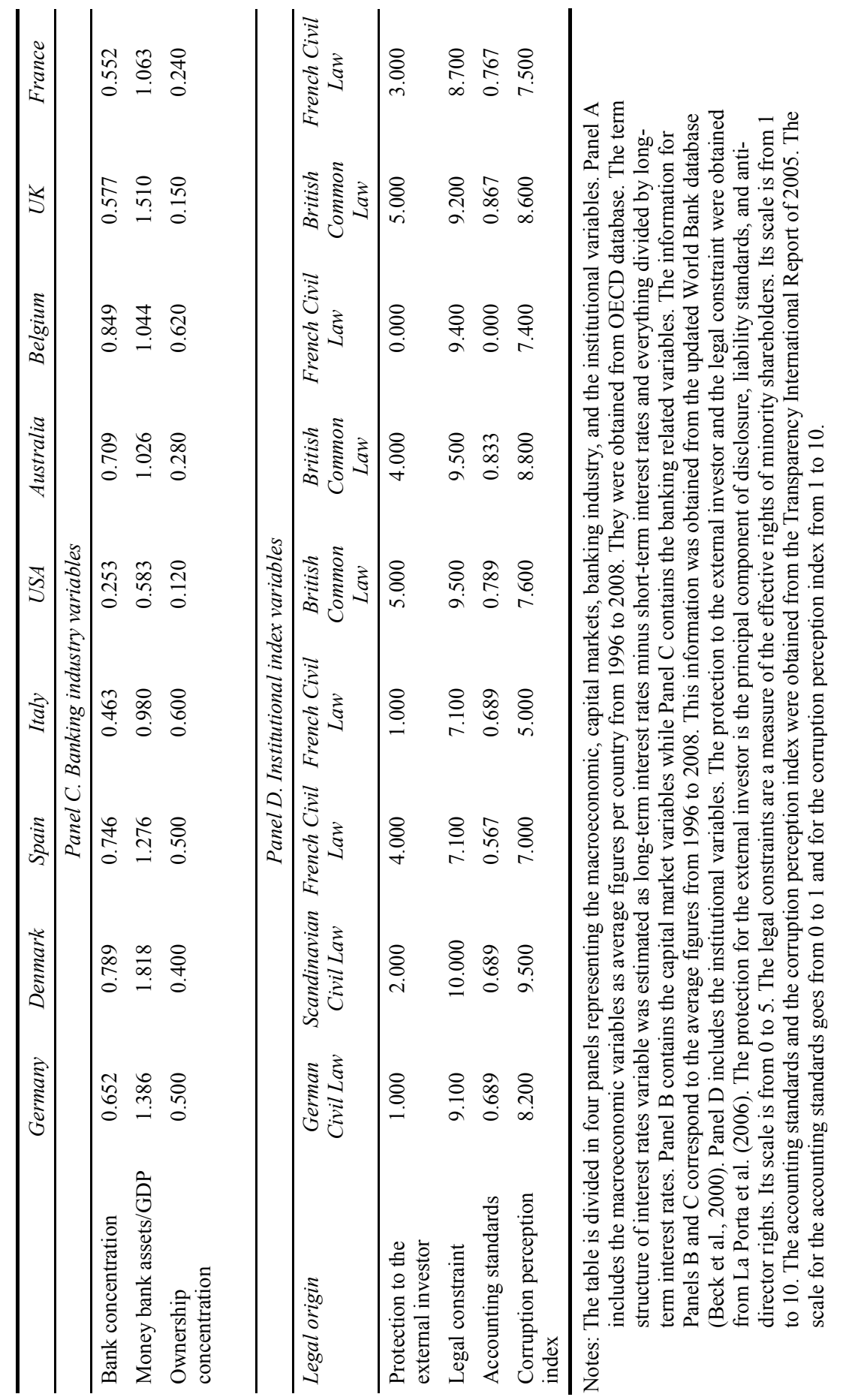


For each of the four groups of variables in which we have divided the country characteristics, we have run a principal component analysis to summarise all the information we have per country and year in just a few factors. These factors have the advantage that they are uncorrelated among them, facilitating the regression analysis. Thus, the macroeconomic variables (Panel A, Table 2) are summarised in two factors: FM1 and FM2, that explain $67 \%$ of the original total variance. The capital market variables (Panel B, Table 2) are summarised in two factors: FCM1 and FCM2 that explain $66 \%$ of the original total variance. The factor FBI1 summarises the information included in the banking industry variables (Panel C, Table 2) explaining 59\% of the original total variance. Finally, the factors: FII1 and FII2 explain $86 \%$ of the variance in original variables that appear in Panel D of Table 2 as the institutional index.

\section{Econometric model}

Panel data econometrics is the most efficient tool to use when the sample is a mixture of time series and cross-sectional data. There are two main advantages of panel data: it overcomes the unobservable and constant heterogeneity of each firm (competitive advantages and strategies, management quality and style, etc.), providing information about earlier time periods for the studied relationships (Bond, 2002); and it helps solve the problem of simultaneity, given that some of the independent variables included in our integrated model, such as the growth opportunities and the deficit of funds, might be determined simultaneously by the dependent variable ${ }^{7}$. Since our models do not satisfy strict exogeneity we used transformations and instruments to eliminate the unobservable effects (Wooldridge, 2002). Thus, we decided to use the two-step system estimator (SE) with adjusted standard errors for potential heteroskedasticity (Blundell and Bond, 1998), transforming the variables into first differences and using the generalised method of moments (GMM) to deal with endogeneity problems (Blundell and Bond, 1998; Hansen, 1996; Levine et al., 2000; Windmeijer, 2005). Given that our main goal is to study the dynamics of adjustment to the target debt maturity ratio, we used the dynamic dimension of panel data which allows us to check out the response processes across time and identify how the different determinants included in our integrated model explain the maturity structure decisions.

To test the model specifications' validity, we use the Hansen/Sargan test of over identification of restrictions. This test examines the lack of correlation between the instruments and the error term. The AR1 and AR2 statistics measure first- and second-order serial correlation ${ }^{8}$. We also compute the Wald-test of joint significance for all independent variables. Furthermore, we use the adjustment for small samples suggested by Windmeijer (2005). Since our sample size for the analysis per country is not very large, the Windmeijer proposal improves the robustness of our results and avoids any potential downward bias in the estimated asymptotic standard errors.

We develop an empirical model to estimate the adjustment speed to the target debt maturity for the whole sample, by country and by institutional environment. To explore the differences by country, observed in the adjustment speed to the target maturity structure, we run a principal components analysis considering just one observation per country, the average value for the period 1996-2008, for each of the four categories in which we divide the indicators by country that appear in Table 2 . Then, using the values of the four components, one for each panel in Table 2, and the speed of adjustment per 
country, we run a K-means cluster analysis to identify how the countries in our sample can be split in two groups and which variables are statistically significant to explain the groupings.

Analytically, the regression model is:

$$
\begin{aligned}
\text { LTDTD }_{i, t} & =\alpha_{0}+\alpha_{1} \cdot \text { LTDTD }_{i, t-1}+\alpha_{2} \cdot Q_{i, t}+\alpha_{3} \cdot \operatorname{VSALES}_{i, t}+\alpha_{4} \cdot \text { DEF }_{i, t} \\
& +\alpha_{5} \cdot Z_{i, t}+\alpha_{6} \cdot \text { LNTAB }_{i, t}+\alpha_{7} \cdot \text { ROA }_{i, t}+\alpha_{8} \cdot \text { NDTS }_{i, t} \\
& +\alpha_{9} \cdot \text { INSTITUTIONAL }_{c, t}+v_{i, t}
\end{aligned}
$$

With

$$
\begin{aligned}
& \alpha_{1}=(1-\lambda) \\
& \alpha_{j}=\lambda \cdot \beta_{j} \\
& v_{i, t}=\varepsilon_{i, t}-(1-\lambda) \cdot \varepsilon_{i, t-1}
\end{aligned}
$$

The parameter corresponding to the lagged dependent variable $\alpha_{1}=(1-\lambda)$ measures the adjustment costs. $\lambda$ measures the adjustment speed to the target debt maturity. Once an estimation of $\lambda$ is obtained through the dependent lagged variable $L T D T D_{i, t-1}$, we can compute the $\beta_{j}$ coefficients of equation (3) by dividing each $\alpha_{j}$ by $\lambda$. The speed of adjustment can be interpreted as the achieved percentage of the target debt maturity ratio by the firm during one year. The higher the coefficient, the closer to the target debt maturity ratio the firm will be.

The subindex $t$ refers to each of the years covered in the analysis, from 1996 to 2008. The subindex $i$ refers to each of the companies included in the sample whereas the sub index $c$ is for each of the nine countries.

First, we run the regression model over the whole sample; then we run the regression model by country ${ }^{9}$ to observe the differences in adjustment speed among the pairs of countries, and then between each of the countries, and the whole.

Finally, we classify the countries in our sample into two groups by the speed of adjustment, macroeconomic conditions, capital markets development, bank industry relevance, and institutional index. Before conducting the cluster analysis we perform a principal component analysis to summarise all the information we have per country. We use one component for each of the four groups of variables presented in Table 2: macroeconomic component, capital markets component, bank industry component and institutional index component. In the last step we run the regression model separately for the two clusters obtained from the K-means analysis.

\section{Results}

To test our hypothesis empirically we begin by regressing the firms' characteristics and institutional variables for the whole sample, first with the OLS and with-in estimator, and then using the $\mathrm{SE}^{10}$. This is done to test the influence of both types of variables on the adjustment process to the optimal proportion of long-term debt (maturity structure), considering at the same time different means of estimations to deal with the mean reversion critique (Chang and Dasgupta, 2009). 
Table 3 The adjustment speed to the optimal debt maturity ratio

\begin{tabular}{|c|c|c|c|c|c|c|}
\hline & Regress 1 & Regress 2 & Regress 3 & Regress 4 & Regress 5 & Regress 6 \\
\hline Intercept & -0.1022 & -0.0971 & -0.1473 & -0.0710 & -0.0528 & -0.1702 \\
\hline (P-value) & $(0.0000)$ & $(0.0310)$ & $(0.0050)$ & $(0.0650)$ & $(0.1650)$ & $(0.0040)$ \\
\hline \multirow{2}{*}{$\operatorname{LTDTD}_{\mathrm{t}-1}$} & 0.6001 & 0.6153 & 0.5984 & 0.6146 & 0.6116 & 0.5709 \\
\hline & $(0.0000)$ & $(0.0000)$ & $(0.0000)$ & $(0.0000)$ & $(0.0000)$ & $(0.0000)$ \\
\hline Adjustment speed & 0.3999 & 0.3847 & 0.4016 & 0.3854 & 0.3884 & 0.4291 \\
\hline \multirow[t]{2}{*}{ Q } & 0.0015 & 0.0024 & 0.0020 & 0.0010 & 0.0015 & 0.0049 \\
\hline & $(0.0550)$ & $(0.0341)$ & $(0.0384)$ & $(0.0667)$ & $(0.5110)$ & $(0.0700)$ \\
\hline \multirow[t]{2}{*}{ VSALES } & -0.0581 & -0.0422 & -0.0611 & -0.0660 & -0.0656 & -0.0401 \\
\hline & $(0.0000)$ & $(0.0010)$ & $(0.0000)$ & $(0.0000)$ & $(0.0000)$ & $(0.0060)$ \\
\hline \multirow[t]{2}{*}{ DEF } & 0.1020 & 0.1026 & 0.0938 & 0.0902 & 0.0910 & 0.1044 \\
\hline & $(0.0000)$ & $(0.0000)$ & $(0.0000)$ & $(0.0000)$ & $(0.0000)$ & $(0.0000)$ \\
\hline \multirow[t]{2}{*}{ Z } & -0.0156 & -0.0160 & -0.0178 & -0.0153 & -0.0151 & -0.0173 \\
\hline & $(0.0000)$ & $(0.0000)$ & $(0.0000)$ & $(0.0000)$ & $(0.0000)$ & $(0.0000)$ \\
\hline \multirow[t]{2}{*}{ LNTAB } & 0.0252 & 0.0246 & 0.0284 & 0.0208 & 0.0197 & 0.0319 \\
\hline & $(0.0000)$ & $(0.0000)$ & $(0.0000)$ & $(0.0000)$ & $(0.0000)$ & $(0.0000)$ \\
\hline \multirow[t]{2}{*}{ ROA } & 0.2226 & 0.2256 & 0.2236 & 0.2284 & 0.2314 & 0.2256 \\
\hline & $(0.0000)$ & $(0.0000)$ & $(0.0000)$ & $(0.0000)$ & $(0.0000)$ & $(0.0000)$ \\
\hline \multirow[t]{2}{*}{ NDTS } & -0.2276 & -0.4109 & -0.2307 & -0.2102 & -0.2114 & -0.3149 \\
\hline & $(0.0150)$ & $(0.0000)$ & $(0.0300)$ & $(0.0460)$ & $(0.0530)$ & $(0.0060)$ \\
\hline \multirow[t]{2}{*}{ FM1 } & & -0.0046 & & & & -0.0069 \\
\hline & & $(0.0010)$ & & & & $(0.0120)$ \\
\hline \multirow[t]{2}{*}{ FM2 } & & -0.0005 & & & & 0.0020 \\
\hline & & $(0.8120)$ & & & & $(0.5890)$ \\
\hline \multirow[t]{2}{*}{ FCM1 } & & & -0.0148 & & & -0.0096 \\
\hline & & & $(0.0130)$ & & & $(0.2060)$ \\
\hline \multirow[t]{2}{*}{ FCM2 } & & & -0.0154 & & & -0.0282 \\
\hline & & & $(0.0070)$ & & & $(0.3000)$ \\
\hline
\end{tabular}

Notes: The table contains the results of the regressions for the overall sample for the period 1996-2008. The estimated regressions correspond to the equation (4), where the dependent variable is LTDTD corresponding to the long-term debt over total debt. The independent variables are: the one period lagged long-term debt ratio $\left(\mathrm{LTDTD}_{\mathrm{t}-1}\right)$, the growth opportunities $(\mathrm{Q})$, the changes in output (VSALES), the deficit of funds for financing the variation in the working capital and in the fixed assets (DEF), the bankruptcy risk (Z) corresponding to the Altman Z-Score, the size of the firm (LNTAB), the return on assets (ROA), and the non-debt tax shield (NDTS) measured as the annual depreciation over total assets. FM1 and FM2 are the factors that summarise $67 \%$ of the variance in GDP per capita, inflation, long term interest rates, and term structure of interest rates. FCM1 and FCM2 are the factors that summarise $66 \%$ of the variance in importance of capital markets, private credit by banks, stock and bond market capitalisation. FBI1 is the factor that summarises $59 \%$ of the variance in bank concentration, bank assets and ownership concentration. FII1 and FII2 are the factors that summarise $86 \%$ of variance in protection to external shareholders, legal constraint, accounting standards and corruption indexes. The first figure is the estimated value for the coefficient, the figure in parenthesis is the p-value. 
Table 3 The adjustment speed to the optimal debt maturity ratio (continued)

\begin{tabular}{lcccccc}
\hline & Regress 1 & Regress 2 & Regress 3 & Regress 4 & Regress 5 & Regress 6 \\
\hline FBI1 & & & & -0.0112 & & 0.0297 \\
FII1 & & & $(0.0200)$ & & $(0.2040)$ \\
& & & & 0.0036 & 0.0345 \\
FII2 & & & & $(0.8730)$ & $(0.2160)$ \\
& & & & -0.0197 & -0.0015 \\
AR1 & & & & $(0.5250)$ & $(0.9750)$ \\
& & & & & \\
AR2 & -18.48 & -17.94 & -18.42 & -18.24 & -17.23 & -18.48 \\
& $(0.0000)$ & $(0.0000)$ & $(0.0000)$ & $(0.0020)$ & $(0.0000)$ & $(0.0000)$ \\
Sargan & 2.92 & 2.93 & 3.00 & 2.98 & 2.74 & 2.92 \\
& $(0.4900)$ & $(0.2300)$ & $(0.7010)$ & $(0.3140)$ & $(0.6000)$ & $(0.4900)$ \\
Hansen & & & & & & \\
& 566.50 & 578.85 & 576.61 & 579.56 & 580.50 & 566.50 \\
Wald & $(0.7430)$ & $(0.8410)$ & $(0.4500)$ & $(0.7930)$ & $(0.2400)$ & $(0.7430)$ \\
& 430.16 & 436.04 & 439.16 & 443.05 & 430.08 & 430.16 \\
& $(0.5500)$ & $(0.3080)$ & $(0.2900)$ & $(0.1100)$ & $(0.6130)$ & $(0.5500)$ \\
OBS & $1,323.19$ & $1,301.58$ & $1,317.23$ & $1,326.41$ & $1,297.33$ & $1,323.19$ \\
\hline & $(0.0000)$ & $(0.0000)$ & $(0.0000)$ & $(0.0000)$ & $(0.0000)$ & $(0.0000)$ \\
& & & & & & \\
& 33,731 & 33,731 & 33,731 & 33,731 & 33,731 & 33,731 \\
\hline
\end{tabular}

Notes: The table contains the results of the regressions for the overall sample for the period 1996-2008. The estimated regressions correspond to the equation (4), where the dependent variable is LTDTD corresponding to the long-term debt over total debt. The independent variables are: the one period lagged long-term debt ratio $\left(\mathrm{LTDTD}_{\mathrm{t}-1}\right)$, the growth opportunities $(\mathrm{Q})$, the changes in output (VSALES), the deficit of funds for financing the variation in the working capital and in the fixed assets (DEF), the bankruptcy risk (Z) corresponding to the Altman $\mathrm{Z}$-Score, the size of the firm (LNTAB), the return on assets (ROA), and the non-debt tax shield (NDTS) measured as the annual depreciation over total assets. FM1 and FM2 are the factors that summarise $67 \%$ of the variance in GDP per capita, inflation, long term interest rates, and term structure of interest rates. FCM1 and FCM2 are the factors that summarise $66 \%$ of the variance in importance of capital markets, private credit by banks, stock and bond market capitalisation. FBI1 is the factor that summarises $59 \%$ of the variance in bank concentration, bank assets and ownership concentration. FII1 and FII2 are the factors that summarise $86 \%$ of variance in protection to external shareholders, legal constraint, accounting standards and corruption indexes. The first figure is the estimated value for the coefficient, the figure in parenthesis is the p-value.

Table 3 shows the regression results for the whole sample. The coefficients are estimated using the two steps SE with adjusted standard errors. The institutional variables are summarised in factors that are included in our model. The factors obtained from each of the principal component analysis are uncorrelated among them but the factors from different principal components analysis can be correlated which could introduce problems of multicolinearity. For this reason, we have run a regression with the factors of each principal component analysis: regressions 2, 3, 4 and 5. Finally regression 6 
includes all the factors obtained in the four principal component analysis runs. We provide the results for six separate regressions: no institutional variables, only macroeconomic factors, only capital markets factors, only banking industry factor, only institutional index factors, and all institutional variables.

Our results show that in all of the regressions the coefficient for the adjustment cost is statistically significant with values around 0.6 . This means that the speed of adjustment to the target debt maturity ratio of the companies in our sample is 0.4 (companies achieve their target debt structure in 2.5 years). The variables that are more significant in explaining the optimal debt maturity ratio are: the output decisions (the higher the variation in output, the lower the debt maturity ratio); deficit of funds (the higher the deficit, the higher the proportion of long term debt); bankruptcy risk (high bankruptcy risk means longer debt maturity); size of the company (larger companies show higher proportion of long term debt); profitability (companies with higher ROA have longer debt maturity) and debt tax shields. The results are mostly in agreement with those obtained in other studies (Aggarwal and Aung, 2009; Barclay and Smith, 1995; Lemmon et al., 2008; López, 2005). In particular, the relation between profitability and debt maturity structure is in agreement with the trade-off theory (DeJong and Verwijmeren, 2010). Within the institutional factors, FM1, FCM1, FCM2, and FBI1 are statistically significant. The most relevant country characteristics to explain firms' debt maturity that we have found are inflation rates, the term structure, relevance of capital markets, private credit, stock market capitalisation, bond market size, bank concentration, the size of the banking industry, or ownership concentration.

Thus, these results lead us to conclude that the companies' adjustment processes are conditioned by the institutional environment variables where the firms operate. These findings allow us to deduce that the particular financial system within the different countries explains the firms' debt maturity structure. This result is consistent with Welch's (2004) argument that stock market functioning is a first order determinant of debt ratios.

Once the institutional variables are identified to explain the partial adjustment process to the target debt maturity ratio, we split the sample by country to estimate the differences in the adjustment speed. The SEs obtained in each of the country regressions are in Table 4 . The coefficient estimated for the variable which measures the lagged long-term debt $\left(L T D T D_{t-1}\right)$ is equal to $1-\lambda_{c}$ which corresponds to the adjustment cost toward the target debt maturity ratio; $\lambda_{c}$ measures the speed of adjustment to the optimal debt ratio for each country. We observe that the Danish companies have the greatest adjustment speed, while the US, UK and Australian companies show the lowest adjustment speed to the target debt maturity.

The results of Table 4 also show a negative and statistically significant relation between the growth opportunities and the debt maturity structure for companies in Germany, Italy, the USA, Australia, Belgium, and France. Thus, the companies in these countries will reduce the maturity of their debt as their growth opportunities increase (Barclay and Smith, 1995; Guedes and Opler, 1996). The result is consistent with the avoidance of financing growth opportunities with long-term debt: once the growth opportunities are exercised, value is generated for the company. On the other hand, the result for British companies is consistent with the findings of Dang (2011) that UK companies control the underinvestment problem by reducing leverage, but not by shortening the maturity of their debt. 
Table 4 The adjustment speed to the optimal debt maturity ratioper country

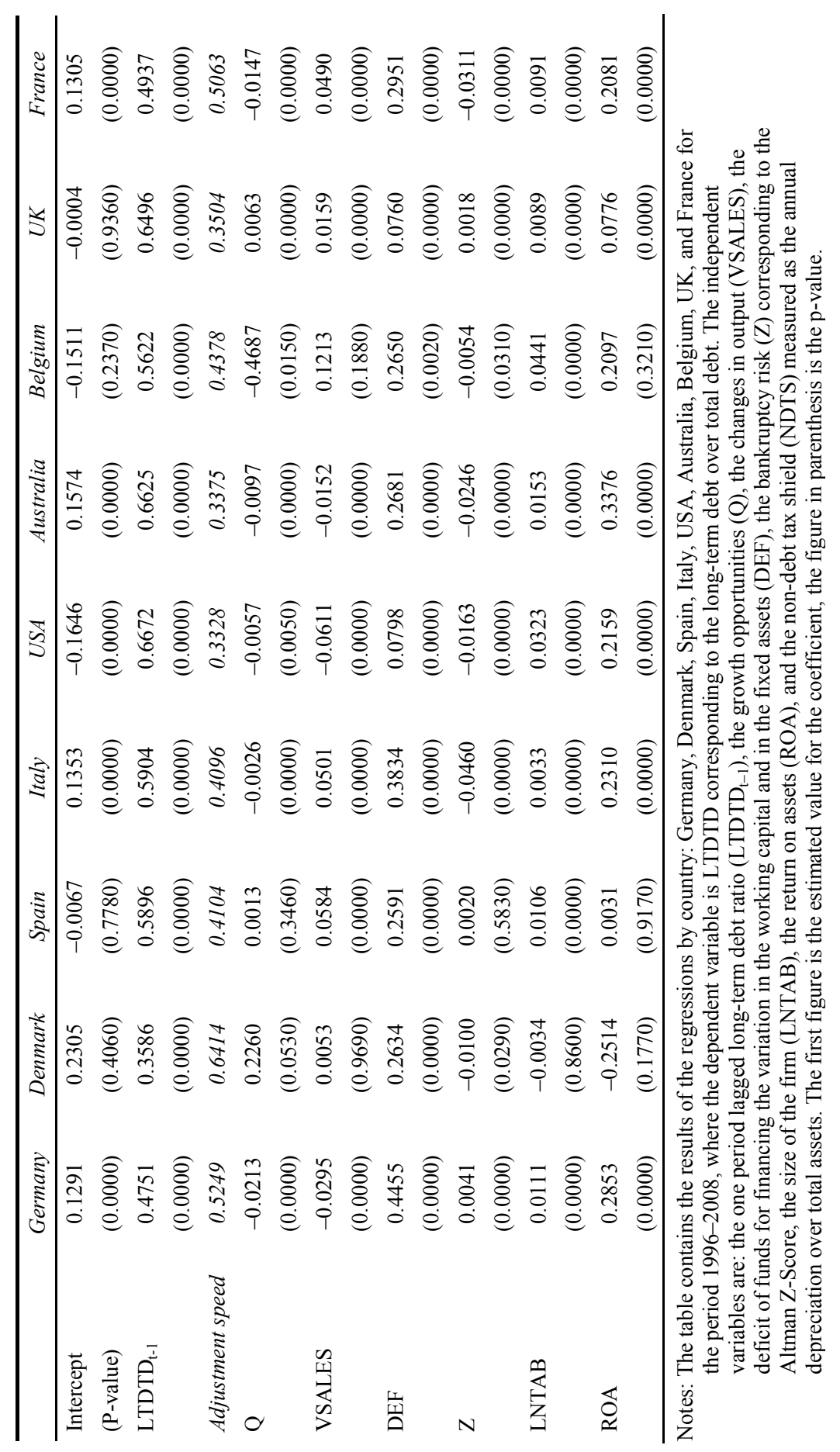


Table 4 The adjustment speed to the optimal debt maturity ratioper country (continued)

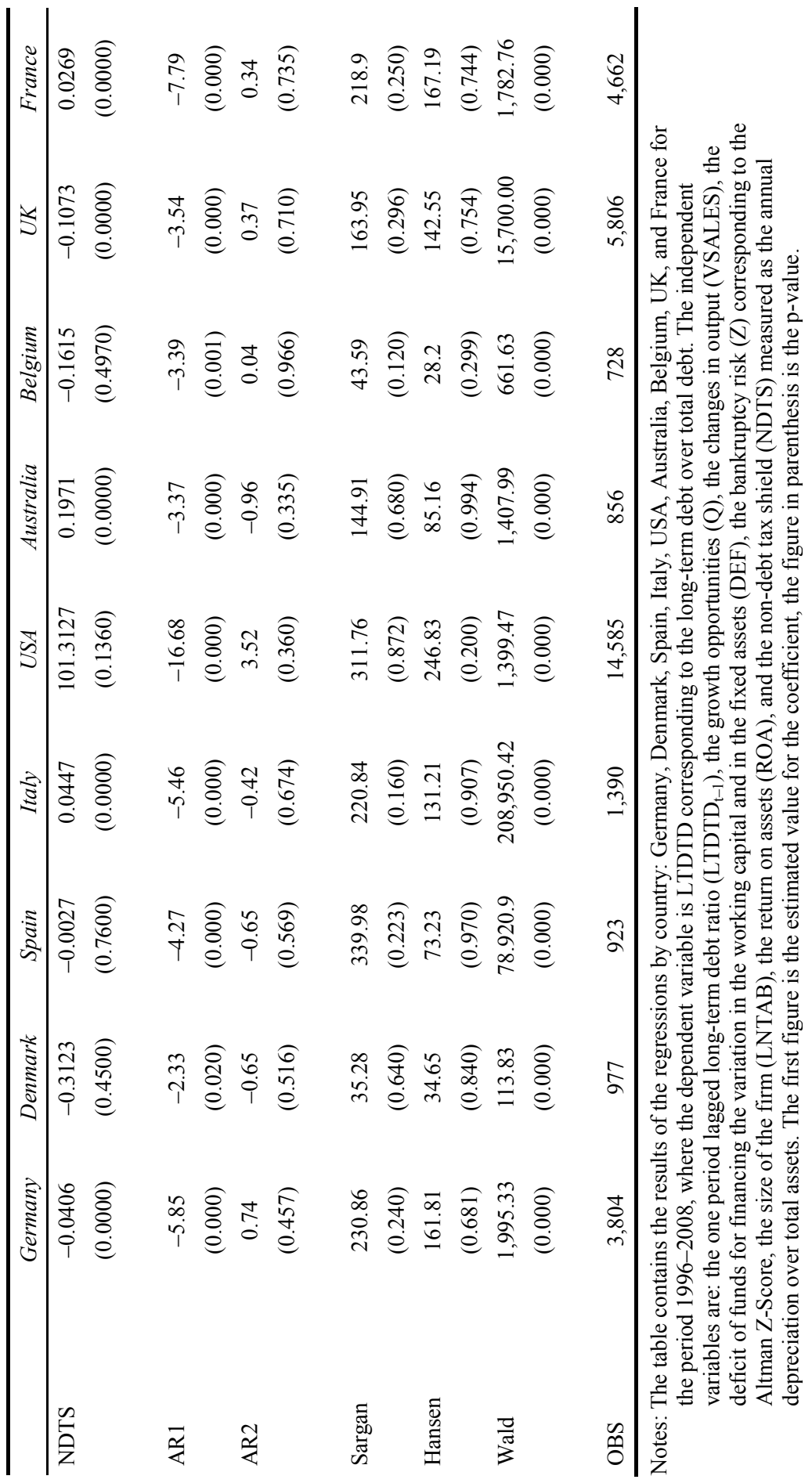


We observe that companies in the various countries present a positive relation between the deficit of funds and the debt maturity structure (Table 4). As the needs for funds are higher, companies show a longer debt maturity ratio which is in agreement with the findings of Denis and McKeon (2010) that firms which generate deficits of funds tend to cover these deficits with more debt. In order to avoid liquidity risk such debt should be long-term. Denmark, Italy, the US, Australia and Belgium show a negative and statistically significant relationship between the risk of bankruptcy, measured through Altman's Z-Score (Z), and the proportion of long-term debt over total debt; those companies with lower risk of bankruptcy use lower proportions of long-term debt in the books. On the other hand, German and British companies tend to use more long-term debt as their bankruptcy risk increases. In this case, companies which find themselves near bankruptcy prefer long-term debt, thus deferring liquidity risk.

Firms in our sample present a positive relationship between the size of the company (LNTAB) and the level of long-term debt (LTDTD) as predicted by Barclay and Smith (1995) and Guedes and Opler (1996). These findings show that the biggest companies have a greater capacity to extend debt maturity because the creditors have greater and better sources of information to evaluate those companies (Core, 2001; Healy and Palepu, 2001). The size of the company is also potentially related to the maturity of the debt (Barclay et al., 2003; Barclay and Smith, 1995). The cost of issuing market debt imposes a minimum volume favouring the larger companies who end up benefiting from economies of scale.

The relation between the maturity of debt and the ROA of the companies is positive and statistically significant for the countries in the sample. These results can be supported by the market timing theory where firms are more likely to issue equity when their market values are high, relative to book and past market values, and to repurchase equity when their market values are low (Baker and Wurgler, 2000, 2002; Becker et al., 1999; Hovakimian, 2005; Schultz, 2003); and by the trade-off theory (DeJong and Verwijmeren, 2010; Jun and Jen, 2003).

There are differences in the speed of adjustment among countries and a coincidence in the fundamental variables that influence the debt maturity ratio. Thus, we wondered if we could classify the countries in our sample by their speed of adjustment but also by their macroeconomic conditions, their capital markets, their financial institutions, and their institutional characteristics. Consequently, using the macroeconomic and institutional variables along with the speed of adjustment estimates we ran a K-means cluster analysis to classify the countries in our sample into two groups. Based on the results of the cluster analysis, we divided the sample into two subsamples and regressed each subsample using equation (4).

As the number of institutional variables are large (15) and the number of countries low (9) we summarise the institutional information using the principal component analysis. For each of the group of variables described in Table 2 we have calculated the component variable that explains more than $50 \%$ of the variability of the original variables (Table 5). Finally, we ran a K-means analysis for the two clusters using as explanatory variables the component variable of macroeconomic conditions, the component variable of capital markets, the component variable of banking industry, the component variable of institutional index and the speed of adjustment to the optimal debt maturity ratio. All of these variables are statistically significant in explaining the grouping (Table 6, Panel A). The cluster results indicate that the countries in our sample 
can be divided into two groups that we have named Continental European countries and Anglo Saxon countries (Table 6, Panel B).

Table 5 Principal component analysis of indicators by country

\begin{tabular}{|c|c|c|c|c|}
\hline Component name & $\%$ variance & Eigen value & Original variables & Component matrix \\
\hline \multirow{4}{*}{$\begin{array}{l}\text { Macroeconomic } \\
\text { variables }\end{array}$} & \multirow[t]{4}{*}{$51.135 \%$} & \multirow[t]{4}{*}{2.045} & GDP per capita & 0.455 \\
\hline & & & Inflation & 0.920 \\
\hline & & & $\begin{array}{l}\text { Long term interest } \\
\text { rates }\end{array}$ & 0.543 \\
\hline & & & $\begin{array}{l}\text { Term structure of } \\
\text { interest rate }\end{array}$ & -0.836 \\
\hline \multirow[t]{4}{*}{$\begin{array}{l}\text { Capital markets } \\
\text { variables }\end{array}$} & \multirow[t]{4}{*}{$66.753 \%$} & \multirow[t]{4}{*}{2.670} & $\begin{array}{l}\text { Relevance of capital } \\
\text { markets }\end{array}$ & 0.883 \\
\hline & & & Private credit by banks & 0.806 \\
\hline & & & $\begin{array}{l}\text { Stock market } \\
\text { capitalisation }\end{array}$ & 0.836 \\
\hline & & & $\begin{array}{l}\text { Bond market } \\
\text { capitalisation }\end{array}$ & -0.736 \\
\hline \multirow{3}{*}{$\begin{array}{l}\text { Bank industry } \\
\text { variables }\end{array}$} & \multirow[t]{3}{*}{$63.295 \%$} & \multirow[t]{3}{*}{1.899} & Bank concentration & 0.928 \\
\hline & & & Bank assets & 0.757 \\
\hline & & & $\begin{array}{l}\text { Ownership } \\
\text { concentration }\end{array}$ & 0.682 \\
\hline \multirow[t]{4}{*}{$\begin{array}{l}\text { Institutional } \\
\text { index }\end{array}$} & \multirow[t]{4}{*}{$51.618 \%$} & \multirow[t]{4}{*}{2.065} & $\begin{array}{l}\text { Protection external } \\
\text { investor }\end{array}$ & 0.632 \\
\hline & & & Legal constraints & -0.638 \\
\hline & & & Accounting standards & 0.687 \\
\hline & & & $\begin{array}{l}\text { Corruption perception } \\
\text { index }\end{array}$ & -0.423 \\
\hline
\end{tabular}

Notes: In this table we perform a component analysis to summarise the information of the 15 indicators of Table 2 in 4 variables. We extract one component for each of the four groups identified in Table 2.

Table 6 Cluster analysis results

\begin{tabular}{lcc}
\hline \multicolumn{3}{c}{ Panel A. Variables for the cluster analysis } \\
\hline Cluster variables & F value & $($ P-value $)$ \\
\hline Macroeconomic component & 16.051 & 0.005 \\
Capital markets component & 13.875 & 0.007 \\
Bank industry component & 4.299 & 0.077 \\
Institutional index component & 5.822 & 0.048 \\
Speed of adjustment & 7.668 & 0.028 \\
\end{tabular}

Notes: Panel A includes the variables considered in the cluster analysis, their F statistics and their significance. The first four variables are obtained from the principal component analysis show in Table 6 . The fifth variable is the adjustment speed estimated for each of the countries in the sample (Table 4).

Panel B includes the clusters grouped by the five cluster variables of Panel A. 
Table 6 Cluster analysis results (continued)

\begin{tabular}{lccc}
\hline \multicolumn{3}{c}{ Panel B. Composition of the clusters } \\
\hline Cluster name & Countries in each cluster & Speed of adjustment & Distance between clusters \\
\hline Continental & Germany & 0.5249 & 2.967 \\
Europe & Denmark & 0.6414 & \\
& Spain & 0.4104 & \\
& Italy & 0.4096 & \\
& Belgium & 0.4378 & \\
Anglo Saxon & France & 0.5063 & \\
& USA & 0.3328 & \\
& UK & 0.3504 & \\
& Australia & 0.3375 & \\
\hline
\end{tabular}

Notes: Panel A includes the variables considered in the cluster analysis, their F statistics and their significance. The first four variables are obtained from the principal component analysis show in Table 6 . The fifth variable is the adjustment speed estimated for each of the countries in the sample (Table 4).

Panel B includes the clusters grouped by the five cluster variables of Panel A.

Our results show that the institutional arguments and the speed of adjustment to the optimum debt structure justify the existence of different clusters. In the Continental European countries cluster, integrated by countries that follow the legal doctrine of civil-law, we observe that firms' speeds of adjustment are higher, that they tend to have lower long-term interest rates, positive slope yield curves of interest rates, less capitalised capital markets, high ownership concentration, more relevant banking industries, and a lower institutional index than the companies operating in Anglo Saxon countries.

In addition, we apply a mean difference analysis among the speed of adjustment estimates per country. The results show that the cost of adjustment to the debt maturity structure is not statistically different among the three Anglo Saxon countries in our sample (Table 8). Furthermore, we observe no statistically significant differences among the cost of adjustment estimates of Italy, Spain and Belgium. In the rest of the pair comparisons between countries we observe statistically significant differences in the cost of adjustment to the debt maturity ratio (Table 8 , Panel A).

The adjustment speed for the countries of the Continental European group is in between 0.5567 to 0.5848 whereas the adjustment speed for the Anglo Saxon counties is in the range 0.4228 to 0.5071 (Table 7). The differences in the cost of adjustment between the two clusters of countries are statistically significant (Table 8, Panel B). This indicates that the low costs of adjustment to the target debt maturity ratio allow the Continental European companies to adjust to their optimal debt structure earlier than their counterparts in the Anglo Saxon countries.

There are a number of factors that can explain this difference: the close relationship that the companies in Continental European countries maintain with their creditors (especially with their bank creditors), the greater flexibility of bank debt traditionally used, and the low renegotiation costs of debt allow the companies to adjust to their target maturity faster and in a more dynamic way than in the case of Anglo Saxon companies. 
Table 7 The adjustment speed to the optimal debt maturity ratio by institutional settings

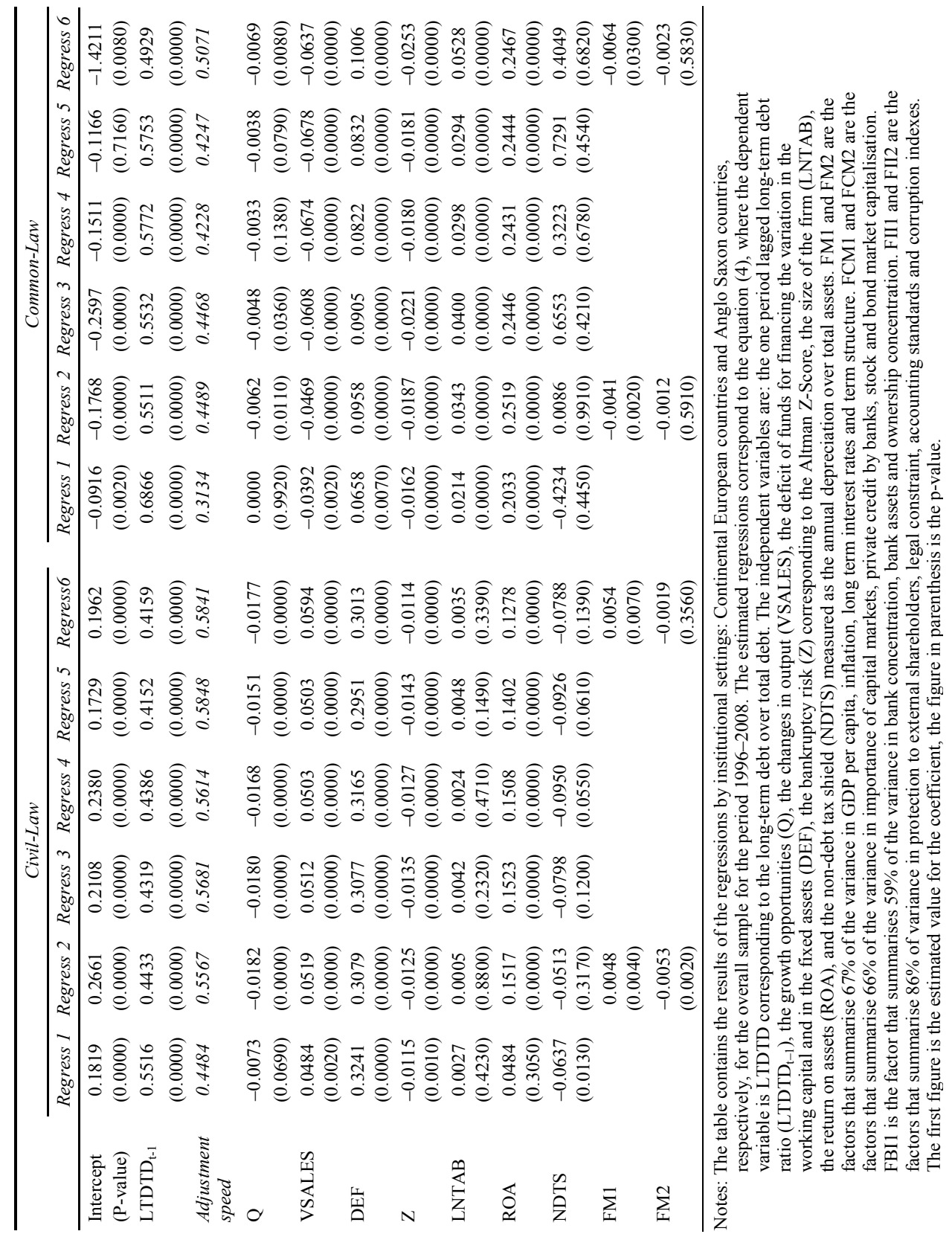


Table 7 The adjustment speed to the optimal debt maturity ratio by institutional settings (continued)

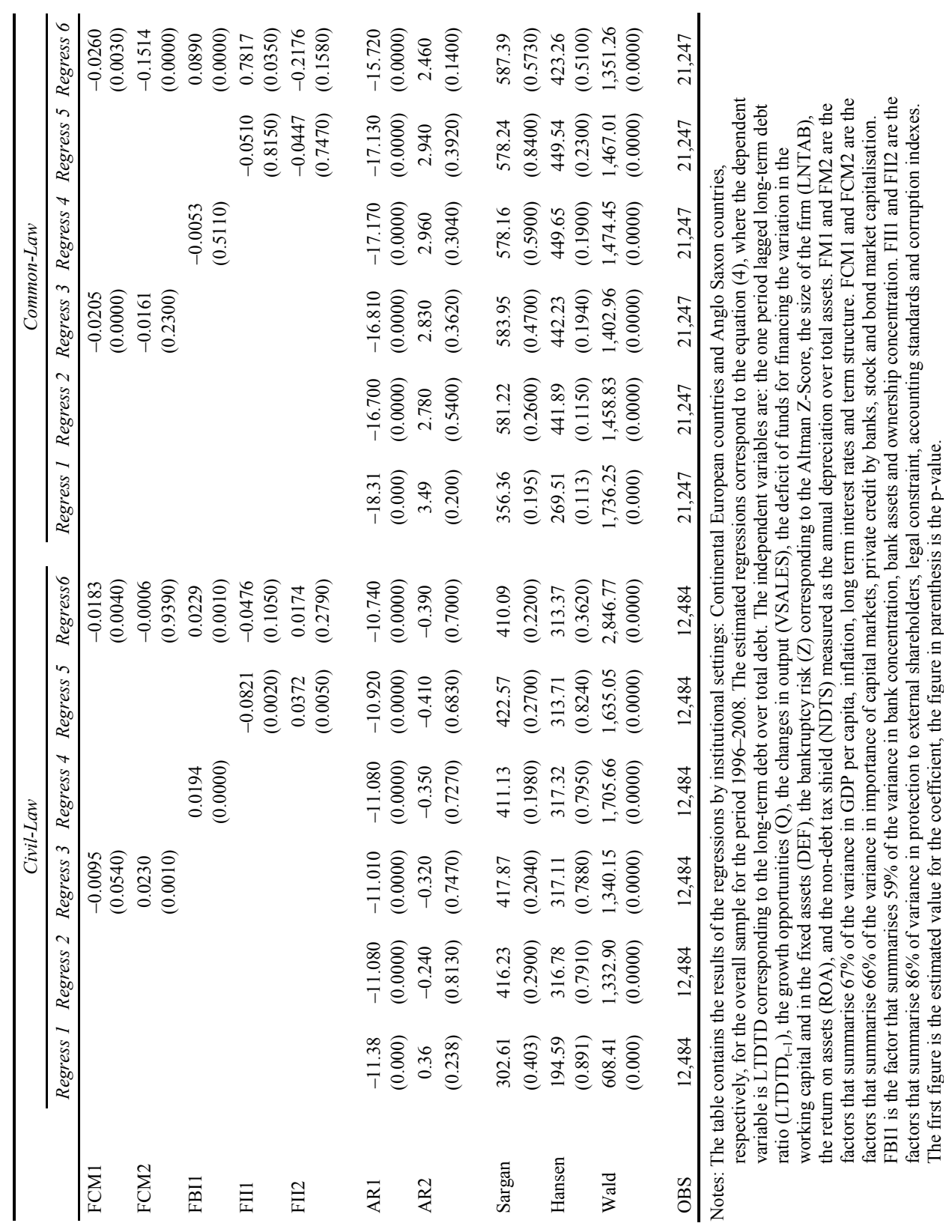


Table 8 Mean difference analysis of the adjustment cost to the target debt maturity ratio

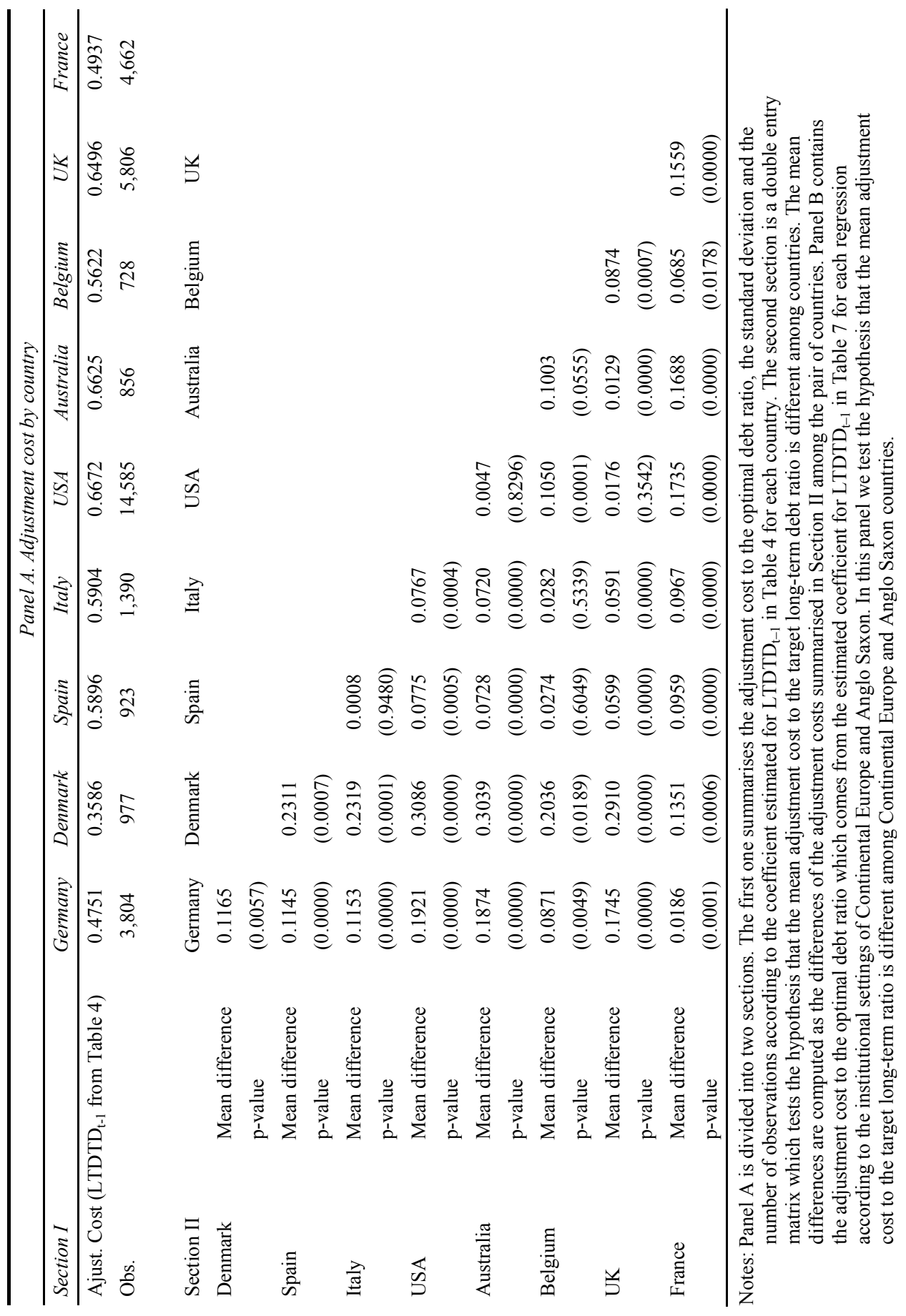


Table 8 Mean difference analysis of the adjustment cost to the target debt maturity ratio (continued)

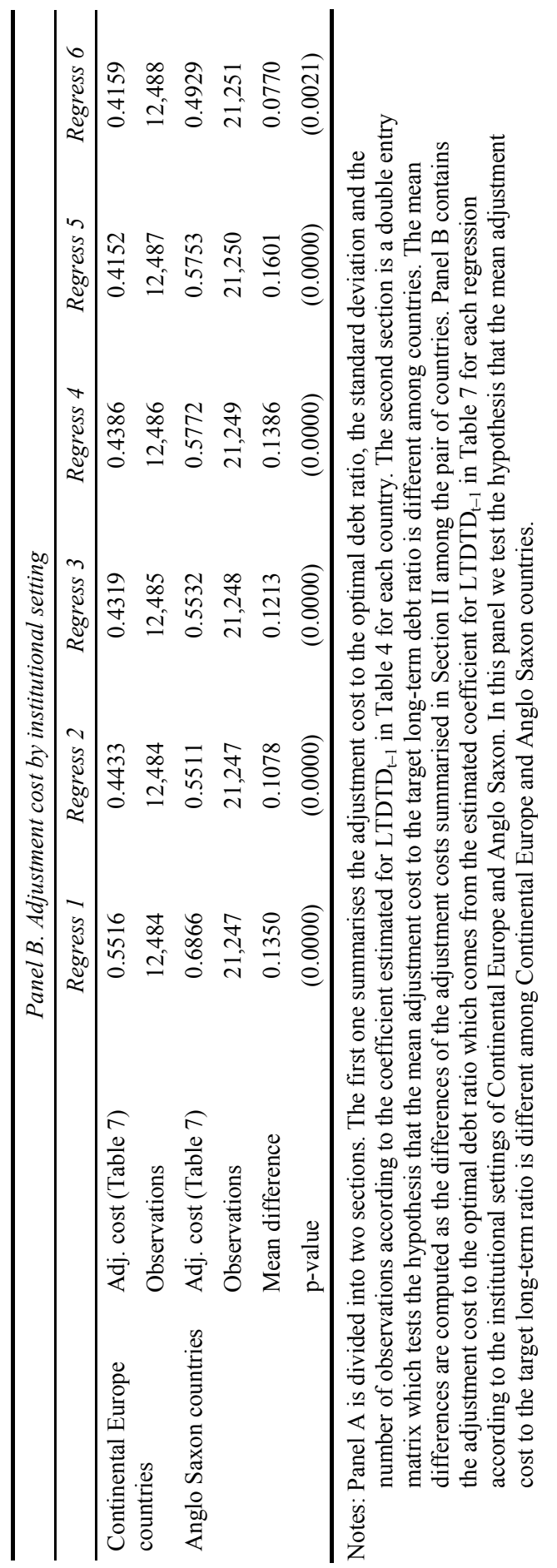


Conversely, Anglo Saxon companies operate in an environment where the relative importance of the capital market determines the financing of the companies, while financing through intermediaries has only a marginal role, primarily for those quoted companies. A situation with these characteristics increases the costs of negotiation of debt as the number of creditors is quite substantial. These institutional characteristics explain the greater costs of adjustment toward the target debt maturity which the companies belonging to the Anglo Saxon countries must face, making the adjustment to the target ratio slower.

Finally, we check the robustness of the results. We re-estimated the different regressions considering our original dependent variable (LTDTD) but this time winsorized at their upper and lower tails at $5 \%$. In addition we have repeated the analysis, winsorizing not only the dependent variable, but also all the company specific variables: Q, VSALES, DEF, Z, LNTAB, ROA and NDTS. This technique takes the non-missing values of the variables but the upper and lower tails at $5 \%$ are replaced by the next value counting inwards from the extremes. Once again, the results are similar and consistent to those previously reported. ${ }^{11}$

\section{Conclusions}

This article presents a cross-country study of companies' adjustment process to their target corporate debt maturity. We estimate the optimal debt maturity from firm-specific variables that integrate the postulates of the main capital structure theories, complemented with arguments of the law and finance approach as our theoretical focus. The analysis is carried out with a sample of listed companies in Germany, Denmark, Spain, Italy, the USA, Australia, Belgium, the UK, and France for the years between 1996 and 2008.

Our first conclusion is that the companies follow target debt maturities according to the postulates of the dynamic trade-off theory. However, we observe differences in the speed of adjustment among countries and also between the companies that operate in Continental European countries compared with those companies that operate in the Anglo Saxon environment. The differences in output, deficit of funds, bankruptcy risk, size, profitability, and taxes explain the existence of frictions in the capital markets which affect the capital structure decisions made by the companies. Indeed those elements should be kept in mind at this point as they will have a bearing on the dynamic adjustment to the target debt maturity structure. Companies follow a partial adjustment to the target debt maturity ratio which is consistent with the results of Roberts and Sufi (2009). They find that more than $90 \%$ of long-term debt contracts are renegotiated before maturity indicating that companies adapt their debt maturity to their perceived optimum. The search for this optimum affects the renegotiation of debt contracts, which is the norm, not the exception (Roberts and Sufi, 2009), and such renegotiation depends on the information on company fundamentals as well as on the macroeconomic, legal and institutional conditions.

Furthermore, the macroeconomic environment and the institutions play an important role in the determination of the costs of adjustment to the target debt maturity. As a result, the institutional environment will determine the speed at which the companies adjust to the target debt maturity structure; financial intermediaries can help companies 
reach their target ratio faster. As Aggarwal and Aung (2009) point out, companies' debt structure in developed Continental European countries, with bank-based and developed financial systems, is sensitive to the size of the banking. This finding is rooted in both the close relationship that the companies have with their banks and the lower costs of renegotiation of the debt. Finally, our result is consistent with López and Rodríguez's (2008) conclusion that capital structure decisions indicate that the effect of factors traditionally considered as determinants of capital structure depends on the legal and institutional setting; these differential effects can explain international disparities in capital structure. Our research has also shown that the introduction of some institutional variables improves the explanatory power of our econometrical models.

In summary, the institutional arguments and the dynamic trade-off theory help us to explain the differences observed in the partial adjustment process to the companies' target debt maturity structure. Our results permit us to empirically prove our research hypothesis that the adjustment speed to the optimal capital structure is greater in those institutional environments where banks play a main role as suppliers of funds to quoted firms. The main advantage of the financial system of Continental European countries is that firms benefit from a greater flexibility to adjust to the target debt maturity ratio at a lower cost. This is consistent with the survey results of Graham and Harvey (2001) in which managers recognise that financial flexibility is the most important determinant for the debt structure of firms.

As a future line of research we will try to analyse the composition of the portfolio of debt of firms operating in Continental European countries to see if they present a higher proportion of bank debt in comparison with companies in Anglo Saxon countries to explain their greater flexibility in their speed of adjustment.

\section{Acknowledgements}

The authors would like to thank the two anonymous referees and seminar participants at the Wolpertinger Conference, at the 5th International Finance Conference, at INFINITI Conference, and at the XIX Foro de Finanzas Conference. Financial support from the Spanish Ministry of Education and from the Castilla y León Secretary of Education is also acknowledged. They also thank Catherine Ramberg for editorial assistance. Any errors are the responsibility of the authors.

\section{References}

Aggarwal, R. and Aung, N. (2009) 'International variations in transparency and capital structure: evidence from European firms', Journal of International Financial Management and Accounting, Vol. 20, No. 1, pp.1-34.

Altman, E. (1968) 'Financial ratios, discriminant analysis and the prediction of corporate bankruptcy', The Journal of Finance, Vol. 23, No. 4, pp.589-609.

Andrés, P., López, F., Rodríguez, J. and Vallelado, E. (2005) 'Determinants of bank debt in a continental financial system, evidence from Spanish companies', Financial Review, Vol. 40, No. 3, pp.305-333.

Antoniou, A., Guney, Y. and Paudyal, K. (2008) 'The determinants of corporate debt ownership structure: Evidence from market-based and bank-based economies', Managerial Finance, Vol. 34, No. 12, pp.821-847. 
Arellano, M. and Bover, O. (1990) 'La econometría de datos de panel', Investigaciones Económicas (Segunda Época), Vol. 14, No. 1, pp.3-45.

Azofra, V., Saona, P. and Vallelado, E. (2007) 'Oportunidades de crecimiento y estructura de propiedad como determinantes del apalancamiento de las empresas españolas', Spanish Review of Finance and Accounting, Vol. 36, No. 113, pp.11-30.

Baker, M. and Wurgler, J. (2000) 'The equity share in new issues and aggregate stock returns', The Journal of Finance, Vol. 55, No. 5, pp.2219-2257.

Baker, M. and Wurgler, J. (2002) 'Market timing and capital structure', The Journal of Finance, Vol. 57, No. 1, pp.1-32.

Baltagi, B. (1995) Econometric Analysis of Panel Data, Baffins Lane, Chichester.

Bancel, F. and Mittoo, U. (2004) 'Cross-country determinants of capital structure choice: a survey of European firms', Financial Management, Vol. 33, No. 4, pp.103-132.

Banerjee, S., Heshmati, A. and Wihlborg, C. (2004) 'The dynamics of capital structure', Research in Banking and Finance, Vol. 4, No. 1, pp.275-297.

Barclay, M. and Smith, C. (1995) 'The maturity structure of corporate debt', Journal of Finance, Vol. 50, No. 2, pp.609-631.

Barclay, M., Max, L. and Smith, C. (2003) 'The joint determination of leverage and maturity', Journal of Corporate Finance, Vol. 9, No. 2, pp.149-167.

Beattie, V., Goodacre, A. and Thomson, S.J. (2006) 'Corporate financing decisions: UK survey evidence', Journal of Business Finance \& Accounting, Vol. 33, Nos. 9/10, pp.1402-1434.

Beck, T., Demirgüç-Kunt, A. and Levine, R. (2000) 'A new database on financial development and structure', World Bank Economic Review, Vol. 14, No. 3, pp.597-605.

Becker, C., Ferson, W., Myers, D.H. and Schill, M.J. (1999) 'Conditional market timing with benchmark investors', Journal of Financial Economics, Vol. 52, No. 1, pp.119-148.

Begley, J., Ming, J. and Watts, S. (1996) 'Bankruptcy classification errors in the 1980s: an empirical analysis of Altman's and Ohlson's models', Review of Accounting Studies, Vol. 1, No. 4, pp.267-284.

Berger, A., Espinosa, M., Frame, W. and Miller, N. (2005) 'Debt maturity, risk, and asymmetric information', The Journal of Finance, Vol. 60, No. 6, pp.2895-2923.

Blundell, R. and Bond, S. (1998) 'Initial conditions and moment restrictions in dynamic panel data models', Journal of Econometrics, Vol. 87, No. 1, pp.115-143.

Bond, S. (2002) 'Dynamic panel data models: a guide to micro data methods and practice', Portuguese Economic Journal, Vol. 1, No. 2, pp.141-162.

Booth, L., Aivazian, V., Demirgüç-Kunt, A. and Maksimovic, V. (2001) 'Capital structures in developing countries', The Journal of Finance, Vol. 56, No. 1, pp.87-130.

Brander, J.A. and Lewis, T.R. (1986) 'Oligopoly and financial structure: the limited liability effect', American Economic Review, Vol. 76, No. 5, pp.9-56.

Brick, I.E. and Ravid, S.A. (1991) 'Interest rate uncertainty and the optimal debt maturity structure', The Journal of Financial and Quantitative Analysis, Vol. 26, No. 1, pp.63-81.

Brounen, D., de Jong, A. and Koedijk, K. (2006) 'Capital structure policies in Europe: survey evidence', Journal of Banking \& Finance, Vol. 30, No. 5, pp.1409-1442.

Chang, X. and Dasgupta, S. (2009) 'Target behavior and financing: how conclusive is the evidence?', Journal of Finance, Vol. 64, No. 4, pp.1767-1796.

Chen, L. and Zhao, X. (2006) 'On the relation between market-to-book ratio, growth opportunity, and leverage ratio', Finance Research Letters, Vol. 3, No. 4, pp.253-266.

Chung, K. and Pruitt, S. (1994) 'A simple approximation of Tobin's Q', Financial Management, Vol. 23, No. 3, pp.70-74.

Core, J. (2001) 'A review of the empirical disclosure literature: discussion', Journal of Accounting and Economics, Vol. 31, Nos. 1-2, pp.441-456. 
Custodio, C., Ferreira, M.A. and Da Silva Laureano, L.M. (2010) Why are U.S. Firms Using More Short-Term Debt?, SSRN eLibrary, available at http://ssrn.com/paper=1573074 (accessed on 21 April 2010).

Danbolt, J., Hirst, I. and Jones, E. (2002) 'Measuring growth opportunities', Applied Financial Economics, Vol. 12, No. 3, pp.203-212.

Dang, V.A. (2011) 'Leverage, debt maturity and firm investment: an empirical analysis', Journal of Business Finance \& Accounting, Vol. 38, Nos. 1-2, pp.225-258.

De Angelo, H. and Masulis, R. (1980) 'Optimal capital structure under corporate and personal taxation', Journal of Financial Economics, Vol. 30, No. 1, pp.3-29.

DeJong, A. and Verwijmeren, P. (2010) 'To have a target debt ratio or not: what difference does it make?', Applied Financial Economics, Vol. 20, No. 3, pp.219-226.

Demirgüç-Kunt, A. and Maksimovic, V. (1998) 'Law, finance and firm growth', The Journal of Finance, Vol. 53, No. 6, pp.2107-2137.

Demirgüç-Kunt, A. and Maksimovic, V. (1999) 'Institutions, financial markets and firm debt maturity', Journal of Financial Economics, Vol. 54, No. 3, pp.295-336.

Demirgüç-Kunt, A. and Maksimovic, V. (2002) 'Funding growth in bank-based and market-based financial systems: evidence from firm-level data', Journal of Financial Economics, Vol. 65, No. 3, pp.337-363.

Denis, D. and McKeon, S. (2010) Debt Financing and Financial Flexibility: Evidence from Pro-Active Leverage Increases, SSRN eLibrary, available at http://ssrn.com/paper=1361171 (accessed on 29 December 2010).

Dennis, S.A. and Sharpe, I.G. (2005) 'Firm size dependence in the determinants of bank term loan maturity', Journal of Business Finance \& Accounting, Vol. 32, Nos. 1-2, pp.31-64.

Dewatripont, M. and Tirole, J. (1994) 'A theory of debt and equity; diversity of securities and management-shareholders congruence', Quarterly Journal of Economics, Vol. 109, No. 4, pp.1027-1054.

Diamond, D. (1991) 'Debt maturity and liquidity risk', Quarterly Journal of Economics, Vol. 106, No. 3, pp.709-737.

Diamond, D.W. and He, Z. (2010) A Theory of Debt Maturity: The Long and Short of Debt Overhang, SSRN eLibrary, available at http://ssrn.com/paper=1539650 (accessed on 26 December 2010).

Djankov, S., La Porta, R., Lopez-de-Silanes, F. and Shleifer, A. (2008) 'The law and economics of self-dealing', Journal of Financial Economics, Vol. 88, No. 3, pp.430-465.

Drobetz, W. and Wanzenried, G. (2006) 'What determines the speed of adjustment to the target capital structure?', Applied Financial Economics, Vol. 16, No. 13, pp.941-958.

Etro, F. (2010) 'Endogenous market structures and the optimal financial structure/Structures de marché endogènes et structure financière optimale', Canadian Journal of Economics/Revue Canadienne d'Économique, Vol. 43, No. 4, pp.1333-1352.

Fama, E. and French, K. (2002) 'Testing trade-off and pecking order predictions about dividend and debt', Review of Financial Studies, Vol. 15, No. 1, pp.1-33.

Faulkender, M. and Petersen, M. (2006) 'Does the source of capital affect capital structure?', The Review of Financial Studies, Vol. 19, No. 1, pp.45-79.

Flannery, M. and Rangan, K. (2006) 'Partial adjustment toward target capital structures', Journal of Financial Economics, Vol. 79, No. 3, pp.469-506.

Frank, M. and Goyal, V. (2003) 'Testing the pecking order theory of capital structure', Journal of Financial Economics, Vol. 67, No. 2, pp.217-248.

Frank, M.Z. and Goyal, V.K. (2009) 'Capital structure decisions: which factors are reliably important?', Financial Management, Vol. 38, No. 1, pp.1-37.

Gaud, P., Jani, E., Hoesli, M. and Bender, A. (2005) 'The capital structure of Swiss companies: an empirical analysis using dynamic panel data', European Financial Management, Vol. 11, No. 1, pp.51-69. 
González, F. (2009) 'Determinants of bank-market structure: efficiency and political economy variables', Journal of Money, Credit and Banking, Vol. 41, No. 4, pp.720-735.

Graham, J. and Harvey, C. (2001) 'The theory and practice of corporate finance: evidence from the field', Journal of Financial Economics, Vol. 60, Nos. 2-3, pp.187-243.

Graham, J.R. (1999) 'Do personal taxes affect corporate financing decisions?', Journal of Public Economy, Vol. 73, No. 2, pp.147-185.

Guedes, J. and Opler, T. (1996) 'The determinants of the maturity of corporate debt issues', Journal of Finance, Vol. 51, No. 5, pp.1809-1833.

Gujarati, D. (1990) Econometría, 2nd ed., McGraw-Hill Inc., Bogota.

Haas, R. and Peeters, M. (2006) 'The dynamic adjustment towards target capital structure of firms in transition economies', Economic of Transition, Vol. 14, No. 1, pp.133-169.

Hansen, L. (1996) 'Finite-sample properties of some alternative GMM estimators', Journal of Business and Economic Statistics, Vol. 14, No. 3, pp.262-280.

Healy, P. and Palepu, K. (2001) 'Information asymmetry, corporate disclosure, and the capital markets: a review of the empirical disclosure literature', Journal of Accounting and Economics, Vol. 31, Nos. 1-3, pp.405-440.

Himmelberg, C., Hubbard, R. and Palia, D. (1999) 'Understanding the determinants of managerial ownership and the link between ownership and performance', Journal of Financial Economics, Vol. 53, No. 3, pp.353-384.

Houston, J.F. and Venkataraman, S. (1994) 'Optimal maturity structure with multiple debt claims', The Journal of Financial and Quantitative Analysis, Vol. 29, No. 2, pp.179-197.

Hovakimian, A. (2005) 'Are observed capital structures determined by equity market timing?', Journal of Financial and Quantitative Analysis, Vol. 41, No. 1, pp.221-243.

Hovakimian, A., Hovakimian, G. and Tehranian, H. (2004) 'Determinants of target capital structure: The case of dual debt and equity issues', Journal of Financial Economics, Vol. 71, No. 3, pp.517-540.

Hovakimian, A., Opler, T. and Titman, S. (2002) 'The capital structure choice: new evidence for a dynamic tradeoff model', Journal of Applied Corporate Finance, Vol. 15, No. 1, pp.24-30.

Huang, R. and Ritter, J. (2009) 'Testing theories of capital structure and estimating the speed of adjustment', Journal of Financial and Quantitative Analysis, Vol. 44, No. 2, pp.237-271.

Johnson, S. (1997a) 'An empirical analysis of the determinants of corporate debt ownership structure', Journal of Financial and Quantitative Analysis, Vol. 32, No. 1, pp.47-69.

Johnson, S. (1997b) 'The effect of bank debt on optimal capital structure', Financial Management, Vol. 26, No. 4, pp.47-56.

Jun, S. and Jen, F. (2003) 'Trade-off model of debt maturity structure', Review of Quantitative Finance and Accounting, Vol. 20, No. 1, pp.5-34.

Korajczyk, R. and Levy, A. (2003) 'Capital structure choice: macroeconomic conditions and financial constraints', Journal of Financial Economics, Vol. 68, No. 1, pp.75-109.

Krishnaswami, S. and Subramaniam, V. (1999) 'Information asymmetry, valuation, and the corporate spin-off decision', Journal of Financial Economics, Vol. 53, No. 1, pp.73-112.

Krishnaswami, S., Spindt, P. and Subramaniam, V. (1999) 'Information asymmetry, monitoring, and the placement structure of corporate debt', Journal of Financial Economics, Vol. 51, No. 3, pp.407-434.

La Porta, R., Lopez-De-Silanes, F. and Shleifer, A. (2006) 'What works in securities laws?', Journal of Finance, Vol. 61, No. 1, pp.1-32.

La Porta, R., Lopez-de-Silanes, F., Shleifer, A. and Vishny, R.W. (1997) 'Legal determinants of external finance', The Journal of Finance, Vol. 52, No. 3, pp.1131-1150.

Lang, L., Ofek, E. and Stulz, R. (1996) 'Leverage, investment, and firm growth', Journal of Financial Economics, Vol. 40, No. 1, pp.3-29. 
Lemmon, M.L., Roberts, M.R. and Zender, J.F. (2008) 'Back to the beginning: persistence and the cross-section of corporate capital structure', Journal of Finance, Vol. 63, No. 4, pp.1575-1608.

Levine, R., Loayza, N. and Beck, T. (2000) 'Financial intermediation and growth: causality and causes', Journal of Monetary Economics, Vol. 46, No. 1, pp.31-77.

Lindblom, T., Sandahl, G. and Sjögren, S. (2010) 'Financial structure decisions in large business firms', Paper Presented at the Wolpertinger Conference, 8-10 September, Bangor, UK.

Lindenberg, E. and Ross, S. (1981) 'Tobin's Q ratio and industrial organization', Journal of Business, Vol. 54, No. 1, pp.1-32.

Lööf, H. (2004) 'Dynamic optimal capital structure and technical change', Structural Change and Economic Dynamics, Vol. 15, No. 4, pp.449-468.

López, F. (2005) 'Debt ownership structure and legal system: an international analysis', Applied Economics, Vol. 37, No. 3, pp.355-365.

López, F. and Rodríguez, J. (2008) 'Capital structure and institutional setting: a decompositional and international analysis', Applied Economics, Vol. 40, No. 14, pp.1851-1864.

López, F. and Saona, P. (2005) 'Earnings management and internal mechanisms of corporate governance: empirical evidence from Chilean firms', Corporate Ownership and Control, Vol. 3, No. 1, pp.17-29.

Maksimovic, V. (1988) 'Capital structure in repeated oligopolies', RAND Journal of Economics, Vol. 19, No. 3, pp.389-407.

McClure, K., Clayton, R. and Hofler, R. (1999) 'International capital structure differences among the G7 nations: a current empirical view', European Journal of Finance, Vol. 5, No. 2, pp.141-164.

Miguel, A. and Pindado, J. (2001) 'Determinants of capital structure: new evidence from Spanish panel data', Journal of Corporate Finance, Vol. 7, No. 1, pp.77-99.

Modigliani, F. and Miller, M. (1958) 'The cost of capital, corporation finance and the theory of investment', American Economic Review, Vol. 68, No. 3, pp.261-297.

Modigliani, F. and Perotti, E. (1997) 'Protection of minority interest and the development of security markets', Managerial and Decision Economics, Vol. 18, Nos. 7-8, pp.519-528.

Morris, J. (1976) 'On corporate debt maturity strategies', Journal of Finance, Vol. 31, No. 1, pp.29-37.

Myers, S. (1977) 'Determinants of corporate borrowing', Journal of Financial Economics, Vol. 5, No. 2, pp.147-175.

Myers, S. (1984) 'Capital structure puzzle', The Journal of Finance, Vol. 39, No. 3, pp.575-593.

Myers, S. (1993) 'Still searching for optimal capital structure', Journal of Applied Corporate Finance, Vol. 6, No. 3, pp.4-14.

Ozkan, A. (2002) 'The determinants of corporate debt maturity: evidence from UK firms', Applied Financial Economics, Vol. 12, No. 1, pp.19-24.

Ozkan, A. and Ozkan, N. (2004) 'Corporate cash holdings: an empirical investigation of UK companies', Journal of Banking and Finance, Vol. 28, No. 9, pp.2103-2134.

Parsons, C. and Titman, S. (2008) 'Empirical capital structure: a review', Foundations and Trends in Finance, Vol. 3, No. 1, pp.1-93.

Rajan, R. and Zingales, L. (1995) 'What do we know about capital structure? Some evidence from international data', The Journal of Finance, Vol. 50, No. 5, pp.1421-1460.

Ravid, S.A. (1996) 'Debt maturity, a survey', Financial Markets, Institutions and Instruments, Vol. 5, No. 3, pp.1-69.

Roberts, M. and Sufi, A. (2009) 'Renegotiation of financial contracts: evidence from private credit agreements', Journal of Financial Economics, Vol. 93, No. 2, pp.159-184.

Roodman, D. (2009) 'A note on the theme of too many instruments', Oxford Bulletin of Economics and Statistics, Vol. 71, No. 1, pp.1-37. 
Saona, P. and Vallelado, E. (2010) 'Is the use of bank debt as a governance mechanism conditioned by the financial system? The cases of Chile and Spain', Applied Economics, Vol. 42, No. 13, pp.1709-1726.

Schnabel, J.A. (1984) 'Bankruptcy, interest tax shields and 'optimal' capital structure: a cash flow formulation', Managerial and Decision Economics, Vol. 5, No. 2, pp.116-119.

Schultz, P. (2003) 'Pseudo market timing and the long-run under performance of IPOs', The Journal of Finance, Vol. 58, No. 2, pp.483-517.

Shleifer, A. and Vishny, R. (1997) 'A survey of corporate governance', The Journal of Finance, Vol. 52, No. 2, pp.737-783.

Shyam-Sunder, L. and Myers, S. (1999) 'Testing static tradeoff against pecking order models of capital structure', Journal of Financial Economics, Vol. 51, No. 2, pp.219-244.

Stiglitz, J.E. (1974) 'On the irrelevance of corporate financial policy', American Economic Review, Vol. 64, No. 6, pp.851-866.

Strebulaev, I. (2007) 'Do tests of capital structure theory mean what they say?', The Journal of Finance, Vol. 62, No. 4, pp.1747-1787.

Talberg, M., Winge, C., Frydenberg, S. and Westgaard, S. (2008) 'Capital structure across industries', International Journal of the Economics of Business, Vol. 15, No. 2, pp.181-200.

Thakor, A. (1996) 'The design of financial systems: an overview', Journal of Banking and Finance, Vol. 20, No. 5, pp.917-948.

Titman, S. and Wessels, R. (1988) 'The determinants of capital structure choice', The Journal of Finance, Vol. 43, No. 1, pp.1-19.

Utrero, N. (2007) 'Banking regulation, institutional framework and capital structure: international evidence from industry data', The Quarterly Review of Economics and Finance, Vol. 47, No. 4, pp.481-506.

Vasiliou, D. and Daskalakis, N. (2009) 'Institutional characteristics and capital structure: a cross-national comparison', Global Finance Journal, Vol. 19, No. 3, pp.286-306.

Wanzenried, G. (2003) 'Capital structure decisions and output market competition under demand uncertainty', International Journal of Industrial Organization, Vol. 21, No. 2, pp.171-200.

Wanzenried, G. (2006) 'Capital structure dynamics in the UK and continental Europe', European Journal of Finance, Vol. 12, No. 8, pp.693-716.

Welch, I. (2004) 'Capital structure and stock returns', Journal of Political Economy, Vol. 112, No. 1, pp.106-131.

Windmeijer, F. (2005) 'A finite sample correction for the variance of linear efficient two-step GMM estimators', Journal of Econometrics, Vol. 126, No. 1, pp.25-51.

Wooldridge, J. (2002) Econometric Analysis of Cross Section and Panel Data, MIT Press, Cambridge, MA.

\section{Notes}

1 Direct costs include the legal and administrative costs of liquidation or reorganisation, while the indirect costs involve the impaired ability to conduct business and agency costs of debt that are specially related to periods of high bankruptcy risk (Haas and Peeters, 2006).

2 Along a similar line of reasoning, the work of McClure et al. (1999) on G7 companies, establishes that the financial decisions can also be explained by a group of business and institutional factors classified in the following manner: (1) international issues, such as risk of changes in interest rates, imperfections in the market and opportunities for international diversification; (2) local issues of the country such as the political risk and the governmental politics like the institutional financial policies and attitudes of the national culture; and (3) specific issues of the companies such as the proportion of international business, the industrial classification, the size, the rate of growth, profitability, and the volatility of profits. 
3 The pecking order hypothesis predicts $\lambda$ to be zero, whereas according to the trade-off model the speed of adjustment should be between zero and one (Fama and French, 2002).

4 Following Roodman (2009) we have considered a panel with $T=13$ because a longer time period tends to vitiate the Hansen test for the validity of GMM instruments.

5 Chung and Pruitt (1994) have compared the values of Tobin's Q obtained by the method of Lindenberg and Ross (1981) to the market-to-book ratio, finding that at least $96.6 \%$ of the variability of Tobin's $\mathrm{Q}$ is explained by the market-to-book ratio.

6 The Altman's $Z$ Score is calculated according to the following equation (Altman, 1968): $Z=1.2$ turnover/total assets) +1.4 (retained profits/total assets) $+3,3$ (earnings before interest and taxes/total assets) +0.6 (equity at market value/total liabilities) +1.0 (earnings/total assets).

7 Other advantages using panel data in the analysis of data are the easy control of the individual heterogeneity of the observations (Baltagi, 1995; Himmelberg et al., 1999; López and Saona, 2005). Moreover, panel data contains higher informative contents, higher variability, less colinearity in between the variables, more grades of freedom, and higher efficiency. Arellano and Bover (1990) argue that the panel data analysis allows an assessment of the dynamicity of the adjustments and is better in the identification and measurement of those effects which are not observable either with the cross sectional analysis or the time series analysis.

8 Given the use of first-difference transformations, we expect some degree of first-order serial correlation, although this correlation does not invalidate our results. However, the presence of second-order serial correlation does signal omitted variables.

9 In these regressions there are not institutional factors.

10 For brevity reasons we only report the SE results.

11 These results are available upon request to the authors. 